\title{
Proposing a new conceptual model for the reconstruction of ice dynamics in the SW sector of the Scandinavian Ice Sheet (SIS) based on the reinterpretation of published data and new evidence from optically stimulated luminescence (OSL) dating
}

\author{
Christopher Lüthgens ${ }^{1}$, Jacob Hardt ${ }^{2}$, and Margot Böse ${ }^{2}$ \\ ${ }^{1}$ Institute for Applied Geology, University of Natural Resources and Life Sciences, Vienna, Austria \\ ${ }^{2}$ Department of Earth Sciences, Institute of Geographical Sciences, \\ Physical Geography, Freie Universität Berlin, Berlin, Germany
}

Correspondence: Margot Böse (m.boese@fu-berlin.de)

Relevant dates: $\quad$ Received: 13 December 2019 - Accepted: 21 June 2020 - Published: 30 October 2020

How to cite:

Lüthgens, C., Hardt, J., and Böse, M.: Proposing a new conceptual model for the reconstruction of ice dynamics in the SW sector of the Scandinavian Ice Sheet (SIS) based on the reinterpretation of published data and new evidence from optically stimulated luminescence (OSL) dating, E\&G Quaternary Sci. J., 69, 201-223, https://doi.org/10.5194/egqsj-69-201-2020, 2020.

Abstract:

We propose a new concept of the Weichselian ice dynamics in the south-western sector of the Baltic Sea depression. The review of existing geochronological data from Germany, Denmark and southernmost Sweden in combination with new optically stimulated luminescence (OSL) data from the German Oder Lobe area is the basis for a reassessment and an improvement of previous ice dynamic models. Factors like the pre-existing topography, glaciotectonic features and the occurrence of till beds and inter-till deposits of varying origin are also taken into consideration for our process-based reconstruction of the sedimentary environments close to the ice margin and hence the ice dynamics of the Scandinavian Ice Sheet (SIS). During the early MIS 3 (marine isotope stage), the late MIS 3 and MIS 2, the SIS advanced into present-day terrestrial areas around the south-western Baltic Sea Basin.

The first ice advance during the warming phase in early MIS 3 is poorly documented as the EllundWarnow Advance in Germany but may be correlated with the numerically dated Ristinge Advance in Denmark and Sweden.

The late MIS 3 advance in contrast is reliably documented. It shaped the landforms of the Brandenburg Advance and the maximum Weichselian ice extent in the Oder Lobe area in north-eastern Germany and occurred contemporaneously with the Klintholm Advance in southern Sweden and Denmark. The lack of a corresponding till in various cliff profiles along the Baltic Sea coastline between southern Schleswig-Holstein and the island of Rügen can be explained by the distinct lobate structure of this ice advance, which was strongly guided by the pre-existing low-lying topography. We propose the horst of Bornholm, Denmark, acting as an ice divide, with ice-dammed lakes existing on the lee side between two glacier lobes. This lobate structure had not been considered in previous conceptual models, which led to seemingly conflicting chronological and stratigraphical interpretations. Our in- 
troduction of the lobate structure for the first time resolves these contradictions and integrates the data in a coherent model.

The dynamics of the MIS 2 readvance to the Last Glacial Maximum (LGM) extent were clearly different to the previous advance and were most likely characterized by a more uniformly advancing ice front with a less lobate structure which also overrode the horst of Bornholm and the island of Rügen. This advance reached the maximum Weichselian ice extent in some parts of the south-western SIS, but, in the Oder Lobe area, it is proven to have terminated at a lesser extent than the early MIS 3 advance, but it did shape the most prominent morphological landform record of the last glacial cycle.

In order to advance the reconstruction of Weichselian ice dynamics in the future, we strongly suggest using both an MIS-based terminology and a process-based approach in the interpretation of geochronological data to live up to the dynamic nature of continental ice sheets.

Kurzfassung: $\quad$ Es wird ein neues Konzept für die weichselzeitliche Eisdynamik im südwestlichen Sektor der Ostseesenke vorgestellt. Eine Zusammenstellung der vorliegenden geochronologischen Daten aus Deutschland, Dänemark und dem südlichsten Schweden in Verbindung mit neuen OSL Daten aus dem deutschen Gebiet des Oder-Lobus bildet die Basis für eine Neubewertung und einer daraus resultierenden Verbesserung vorangegangener Modelle zur Eisdynamik. Berücksichtigt werden dabei auch Faktoren wie die großräumige Topographie, glazitektonische Störungen, sowie Tills und faziell unterschiedliche Ablagerungen zwischen Tills. Letztere werden für die prozessbasierte Rekonstruktion der Sedimente nahe des Eisrandes herangezogen und geben ebenfalls Informationen über die Dynamik des skandinavischen Inlandeises. Während des frühen MIS 3, des späten MIS 3 und im MIS 2 überfuhr das Inlandeis um die südwestliche Ostseesenke gelegene, heutige terrestrische Bereiche.

Der erste Vorstoß während der Erwärmung im frühen MIS 3 ist nur lückenhaft als Ellund-Warnow Vorstoß in Deutschland nachgewiesen, aber er ist möglicherweise mit dem datierten Ristinge-Vorstoß in Dänemark und Schweden zu korrelieren.

Hingegen ist der späte MIS 3 Vorstoß gut dokumentiert. Er formte die Landschaft des Brandenburger Stadiums, der maximalen Eisausdehnung, im Gebiet des Oder-Lobus in Nordostdeutschland und ist zeitlich mit dem Klintholm-Vorstoß in Südschweden und Dänemark zu parallelisieren. Das Fehlen des entsprechenden Tills in Kliffprofilen der Ostseeküste zwischen dem südlichen SchleswigHolstein und Rügen kann durch die deutliche, lobenförmige Ausbildung des Eisrandes, der sich stark der Topographie anpasste, erklärt werden. Wir gehen davon aus, dass Bornholm als ein Eisstrompfeiler diente und sich an der Leeseite zwischen den Eisloben Eisstauseen bildeten. Diese Ausbildung von deutlichen Eisloben wurde bisher nicht in konzeptionellen Modellen berücksichtig, was zu Widersprüchen zwischen chronologischen und stratigraphischen Interpretationen führte. Die Einführung des Modells von Eisloben löst erstmalig diese Widersprüche auf und führt alle Daten in einem schlüssigen Modell zusammen.

Die Dynamik des erneuten Vorstoßes im MIS 2 zum LGM (Last Glacial Maximum) unterschied sich deutlich von dem vorangegangenen Eisvorstoß. Die Eisfront war geschlossener und überfuhr sowohl Bornholm als auch Rügen. Dieser Eisvorstoß repräsentiert in einigen Teilen der südwestlichen Ostsee die maximale weichselzeitliche Eisausdehnung, hingegen blieb die Eisausdehnung im Gebiet des Oder-Lobus hinter der des späten MIS 3 zurück. Der Oder-Lobus formte hier jedoch die deutlichsten morphologischen Geländeformen des Weichselglazials.

Für zukünftige Rekonstruktionen der weichselzeitlichen Eisdynamik empfehlen wir, unbedingt einer MIS-basierten Terminologie zu folgen und prozessorientierte Ansätze in die Interpretation der geochronologischen Daten mit einzubeziehen, um der lebhaften Dynamik kontinentaler Eisschilde gerecht zu werden. 


\section{Introduction}

Throughout the last decade, significant progress was made concerning the dating of sediments related to the last glacial cycle in the area of the Scandinavian Ice Sheet (SIS) (summarized in, for example, Hughes et al., 2016). The new ages, adding chronological information over the years, have changed the view on the SIS, with Böse et al. (2012) already in 2012 stressing the time transgressive nature of geomorphological ice-marginal positions. The increasing amount of age data now not only enables a review of the chronology of different sectors of the SIS but also the reconstruction of ice dynamics at different time slices throughout the last glacial cycle. Insight into ice dynamics can especially be gained when taking into account not only the bare ages but also the different processes these ages represent in the advance, stability and decay of ice streams and ice lobes forming the SIS (Lüthgens and Böse, 2011, 2012). Figure 1 shows a graphical summary of this concept. Being aware that information is still lacking to gain a complete reinterpretation of ice dynamics of the SIS for multiple time slices covering the whole temporal and spatial range of the last glacial cycle of the SIS, this study focuses on the south-western sector of the SIS because here a critical amount of geochronological data is now available for a thorough re-evaluation of existing ice dynamic models. Aiming at the reconstruction of the changing ice dynamics and ice configurations in this area, already published chronological data were reviewed, and new ages based on optically stimulated luminescence (OSL) dating are presented for the area of the maximum ice extent of the SIS in northeastern Germany.

Available ages are primarily based on OSL dating techniques applied to glaciofluvial and glaciolacustrine sediments, as well as cosmogenic nuclide exposure ages applied to glacial boulders (Heine et al., 2009; Lüthgens et al., 2010a, b, 2011; Lüthgens and Böse, 2011; HoumarkNielsen et al., 2012; Kenzler et al., 2015, 2016; Hardt and Böse, 2016; Hardt et al., 2016). With more ages becoming available, a discussion has evolved - or rather intensified - concerning the question of the occurrence of a late MIS 3 (marine isotope stage) ice advance reaching beyond the south-western border of the Baltic Sea depression to eastern Denmark and north-eastern Germany. In this paper, we aim to show that seemingly contradictory dating results from different key locations may be explained by using a processbased interpretation of numerical ages in the context of largescale ice dynamic processes and topography. Consequently, this new interpretation provides the foundation for the introduction of a new conceptual model of the glacial advances of the SIS into the western and central part of the North European Plain during the last glacial cycle. In addition, we suggest refraining from the use of (traditional) local terminologies for correlation purposes in favour of an objective MIS-related nomenclature based on the chronostratigraphic interpretation of available data.

\section{Geology and topography of the south-western} Baltic Sea depression

The large majority of morphological, stratigraphical, petrographical and chronological data available for the area under investigation was derived from terrestrial records with a very limited number of results available for records from today's Baltic Sea depression (Kriegers Flak in Anjar et al., 2014, and Adlergrund in Obst et al., 2016). However, geomorphological and geological properties of the Baltic Sea floor must have had a significant influence on the dynamics and routing of the inland ice, especially the Baltic Ice Stream.

The morphology of the south-western Baltic Sea is partly determined by tectonic units which were reshaped by glacial erosional processes during the repeated Quaternary glaciations (Fig. 2). The south-east-north-west stretching tectonic Tornquist-Teisseyre zone splits south of Bornholm into the northern branch, the Sorgenfrei-Tornquist zone and the southern Trans-European Fault (Schack Pedersen and Gravesen, 2010). The island of Bornholm is a horst with Proterozoic crystalline bedrock (Uścinowicz, 2014), mainly granite and gneiss (Jakobsen, 2012), forming the northern half of the island and Palaeozoic sedimentary rocks, mainly sandstone and shale (Jakobsen, 2012), in the south (Schack Pedersen and Gravesen, 2010). The south-western edge of Bornholm and the submarine Rønne Banke, morphologically a south-west stretching prolongation of the island of Bornholm, consist of small areas of Jurassic but mainly of Cretaceous limestone with a thin cover of Quaternary sediments (Schack Pedersen and Gravesen, 2010). This offshore shoal has less than $20 \mathrm{~m}$ water depth. At its south-western end, it becomes even shallower in the Adlergrund area, which was intensely investigated as a wind farm construction site (Obst et al., 2016). Farther to the south-west, the offshore shoal forms transitions to the coastal areas of the island of Rügen. North-west of the Rønne Banke, the Arkona Basin is located which is defined by the $40 \mathrm{~m}$ water depth contour line and which has a maximum depth of $48 \mathrm{~m}$. At the western flank of the Arkona Basin, another very shallow area is located, Kriegers Flak, which is also the location of a wind park and which was investigated by Anjar et al. (2014).

\section{Ice dynamics of the SIS throughout the last glacial cycle}

\subsection{SIS ice dynamics up to early MIS 3}

Available chronological data for the Early and Middle Weichselian are scarce to non-existent. When Houmark-Nielsen (1987) and Lagerlund et al. (1995) published the papers of the ice advances at the south-western sector of the SIS, the dating of glacial deposits was not yet common. These papers are based on structural and lithological analyses such as measurements of clast orientation and gravel composition. The striking results were the reconstruction of a westerly ice flow 
(a)

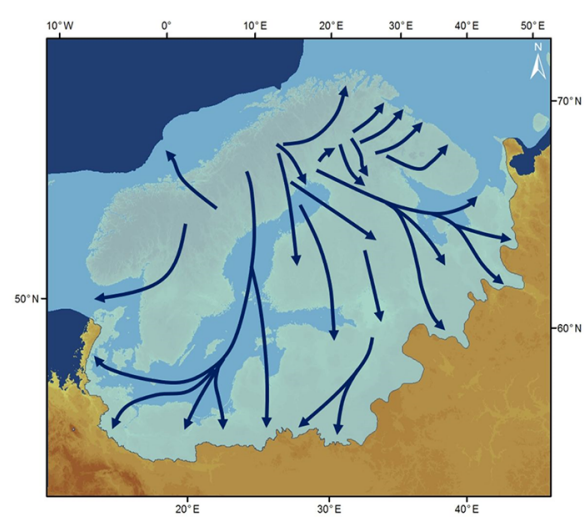

(b)

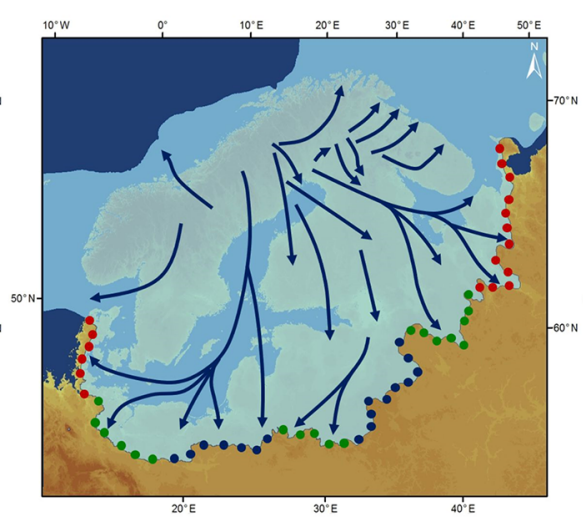

(c)

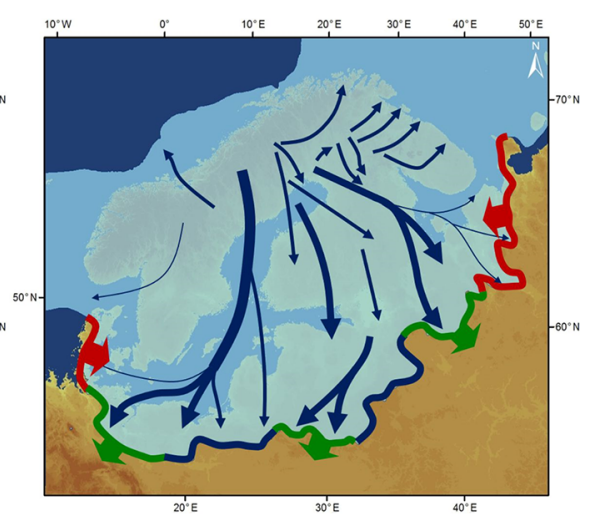

Figure 1. Conceptual model from a static but time transgressive image of the Weichselian SIS extent towards a geochronologically based dynamic interpretation of ice-marginal positions. (a) The base map shows the entire static maximum ice extent of the SIS (data available from Ehlers et al., 2011), which has frequently been shown to be time transgressive. Major ice streams are adapted from Stokes and Clark (2001). (b) Image of a theoretical time slice inferred from geochronological data at ice-marginal positions. A process-based interpretation of these data allows for the identification of sectors characterized by stability (blue), advance (green) and decay (red) of the ice margin. (c) Dynamics of the ice sheet valid for the theoretical time slice and inferred from geochronological information. Red sectors and arrows indicate retreat of the ice front, green sectors and arrows indicate advance of the ice front, and blue sectors indicate stability of the ice front. The thickness of the blue arrows indicates the activity of the individual ice streams inferred from the behaviour at the ice front, with bold arrows implying high activity (resulting in a positive mass balance), medium arrows implying medium activity (stable mass balance) and thin arrows implying low activity (negative mass balance).

direction on the north-western Polish coast and the identification of even a southerly flow component on the eastern coast of Rügen (Lagerlund et al., 1995; Gehrmann and Harding, 2018; Gehrmann and Harding, 2019). Based on these findings, Lagerlund et al. (1995) proposed marginal ice domes at the fringe of the SIS developing their own flow patterns.

In 2010, Houmark-Nielsen presented the so-called Old Baltic Advance in Denmark, now designated as the Ristinge Advance at about 55-50 ka and thus dating to the early MIS 3. The age determination is based on OSL data from quartz and supported by accelerator mass spectrometry (AMS) radiocarbon data of macrofossils in diamicts.

This advance was the maximum Weichselian ice advance in the central part of the Jutland peninsula (Denmark) (Fig. 3). Based on the stratigraphical position, it can be discussed whether this ice advance corresponds to the Ellund Advance in Schleswig-Holstein (Stephan, 2014) and possibly to the Warnow Advance in western MecklenburgWestern Pomerania (Mecklenburg-Vorpommern) (Müller, 2004, 2006). However, there are no numerical ages available for these advances, and they have mainly been reconstructed based on borehole stratigraphy. Neither geomorphological evidence nor correlated sediments could be identified in the coastal profiles at Klütz-Höved (Kenzler et al., 2018), on the German island of Rügen (Kenzler et al., 2016), or in stratigraphical and geomorphological records further south in Brandenburg. In contrast, evidence for correlated sediments of an early MIS 3 advance was found at Kriegers Flak and in the Alnarp Valley in southern Sweden. Anjar et al. (2014, p. 609) consider Kriegers Flak a "potential key site for correlating the glacial stratigraphy of Sweden, Denmark and Germany". At least three till beds have been identified (Anjar et al., 2014), with the lower Weichselian till bed being characterized as a Baltic till, indicating a long distance transport of clasts. This till is attributed to the Ristinge Advance in Denmark. The chronology is based on OSL data (including single grain measurements) of glaciofluvial sand and radiocarbon ages (Anjar et al., 2010, 2012, 2014).

In the southern part of the Swedish Alnarp Valley located in the terrestrial area north of the Arkona Basin, two tills have been identified. The lower till bed is correlated with the Ristinge Till at an age older than $50 \mathrm{ka}$ (Anjar et al., 2014). Möller et al. (2020) recently published numerical data based on quartz OSL and radiocarbon ages from glaciofluvial and glaciolacustrine deposits associated with the deglaciation from the Ristinge Advance. These ages all post-date the presumed age of the Ristinge Advance, thus indirectly confirming it. At the Adlergrund site, Obst et al. (2016) investigated the sedimentary record primarily using lithostratigraphy based on fine gravel analyses. Geochronological data are lacking, but, based on their results, the authors do not present evidence for an early MIS 3 ice advance at the Adlergrund site. Despite the lack of geochronological control, Fig. 3 clearly shows that evidence for an early MIS 3 ice advance of the SIS is only present to the north-west of an idealized line from Bornholm, following the Rønne Banke to the Adlergrund site and the western part of the island of Rügen. To the 


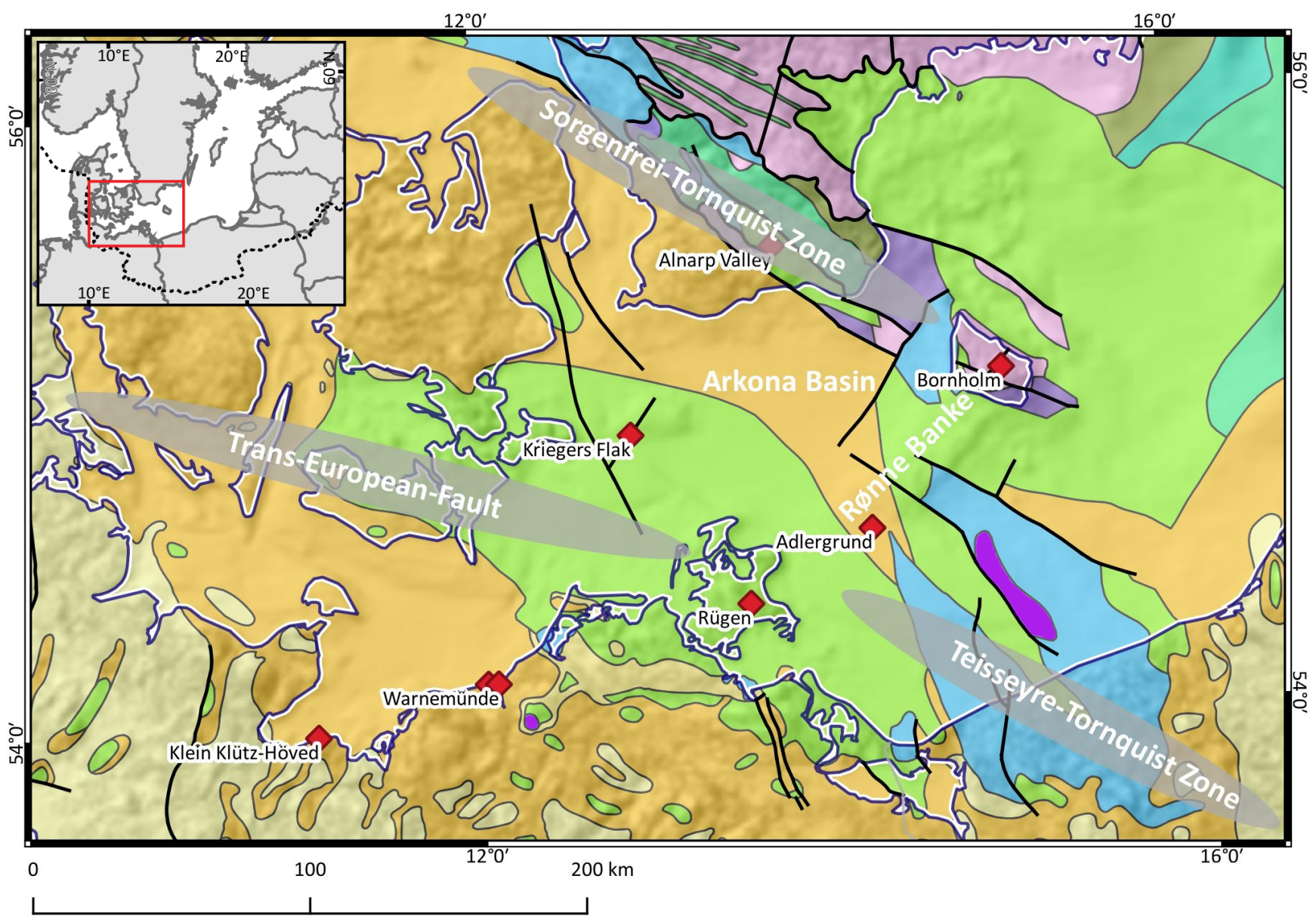

$\checkmark$ Study Sites Stratigraphy

- Geological faults $\square$ Neogene

Cretaceous Silurian

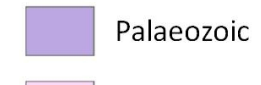

Paleogene - Neogene

Jurassic

Ordovician

Proterozoic

Paleogene

Triassic

Cambrian

Figure 2. Simplified geological map of the south-western Baltic Sea including major fault zones. Geology based on the International Geological Map of Europe (Asch, 2005). Base map: land surface based on $250 \mathrm{~m}$ Shuttle Radar Topography Mission (SRTM) data (Jarvis et al., 2008) and bathymetry based on IOWTOPO1 and IOWTOPO2 (Seifert et al., 2001).

east of that line, no evidence for an early MIS 3 ice advance of the SIS has yet been found.

\subsection{SIS ice dynamics from late MIS 3 to MIS 2}

Compared to the earlier stages of the Weichselian Glaciation, the time constraints and age control starting with late MIS 3 are much better owing to the higher number and better spatial coverage of available data. Table 1 provides a compilation of key studies referred to in this paper, including geochronological, geographical and methodological metadata.

During the late MIS 3, the Klintholm Advance is documented on the island of Møn, Denmark, and is dated to about $30 \mathrm{ka}$ by OSL data from material below and above the till, as well as radiocarbon data of plant macrofossils (HoumarkNielsen, 2010; Houmark-Nielsen et al., 2016). At Kriegers Flak, the lowermost till associated with the Ristinge Advance is overlain by three units of shallow marine brackish sediments in the lower part, followed by terrestrial wetland and lake deposits. The uppermost part of those sediments is formed by a glaciolacustrine clayey deposit. The overlying diamicton can be subdivided into two layers with intercalated sand and gravel.

The lower part could be of the same age as the Klintholm Advance according to the age of underlying organic sediments, whereas the upper layer is only slightly younger and "within the wider range suggested for the Klintholm Till" 

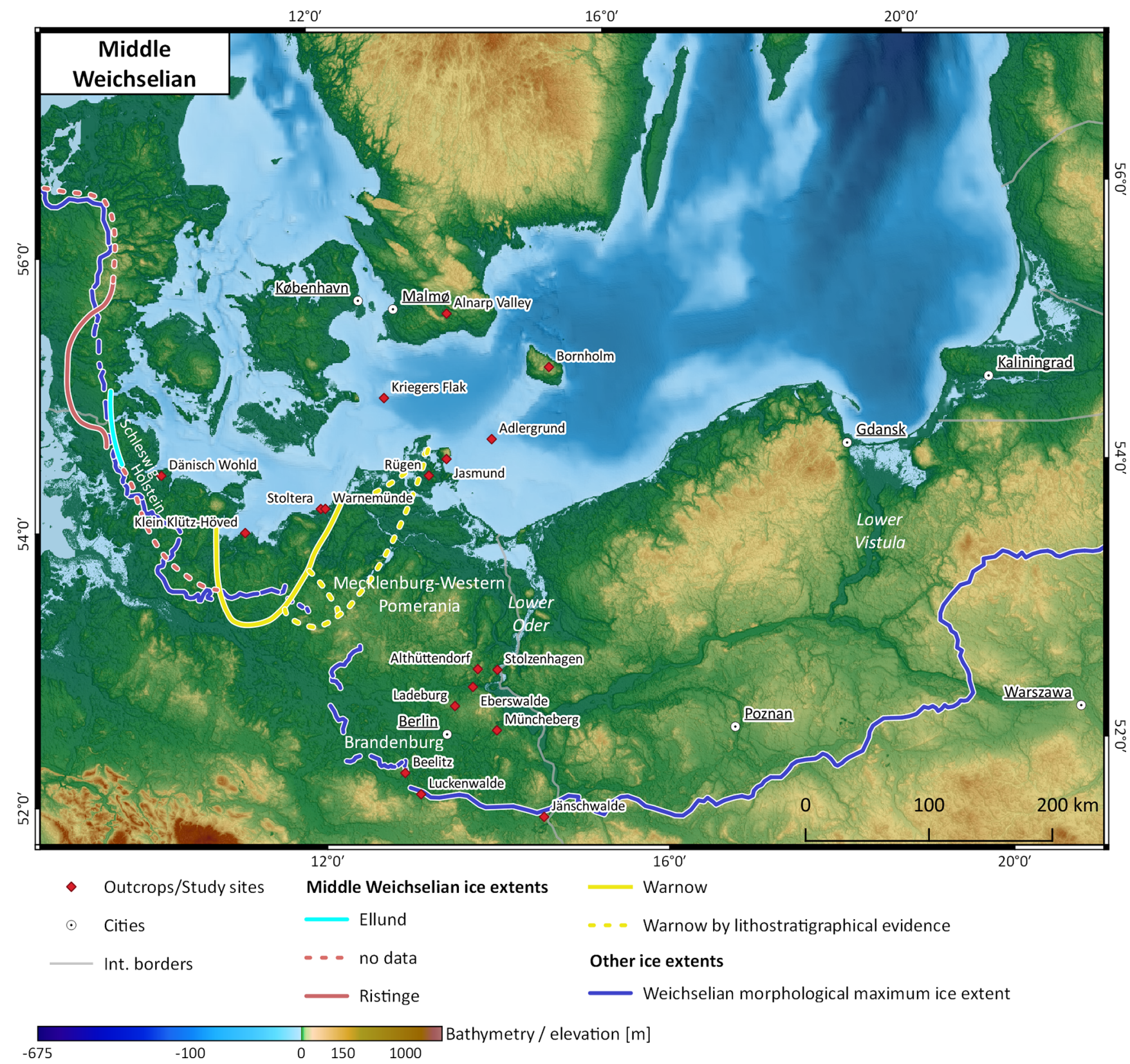

Figure 3. Extents of Middle Weichselian ice advances (Müller, 2004; Houmark-Nielsen, 2010) and Weichselian morphological maximum extent, compiled based on Liedtke (1981) and Marks (2012). Base map: land surface based on $250 \mathrm{~m}$ Shuttle Radar Topography Mission (SRTM) data (Jarvis et al., 2008) and bathymetry based on IOWTOPO1 and IOWTOPO2 (Seifert et al., 2001).

(Anjar et al., 2014:624). In the Alnarp Valley, a till which is restricted to the southern part of the valley and is mainly deposited by a glacier tongue from a south-easterly direction can be found. According to radiocarbon data of underlying sediments, it is younger than $35 \mathrm{kacal} \mathrm{BP}$ (Anjar et al., 2014). It cannot be excluded that the Klintholm Till and the Allarp Till are related to the same ice advance. Möller et al. (2020) recently dated glaciofluvial and glaciolacustrine deposits from different sites in the Alnarp Valley bracketing that till using quartz OSL and radiocarbon dating, establish- ing a time frame for the ice advance and subsequent deglaciation of between 34 and $30 \mathrm{ka}$.

In contrast, in Schleswig-Holstein and western Mecklenburg-Western Pomerania, as well as on Rügen Island and at the Adlergrund site, the available data do not give any evidence of a contemporaneous ice cover during late MIS 3 (Stephan, 2014; Kenzler et al., 2016; PisarskaJamroży et al., 2018, 2019). Widespread glaciolacustrine deposits in parts of the southern Baltic Sea (Steinich, 1992; Panzig, 1997; Anjar et al., 2012) characterize the late MIS 3 


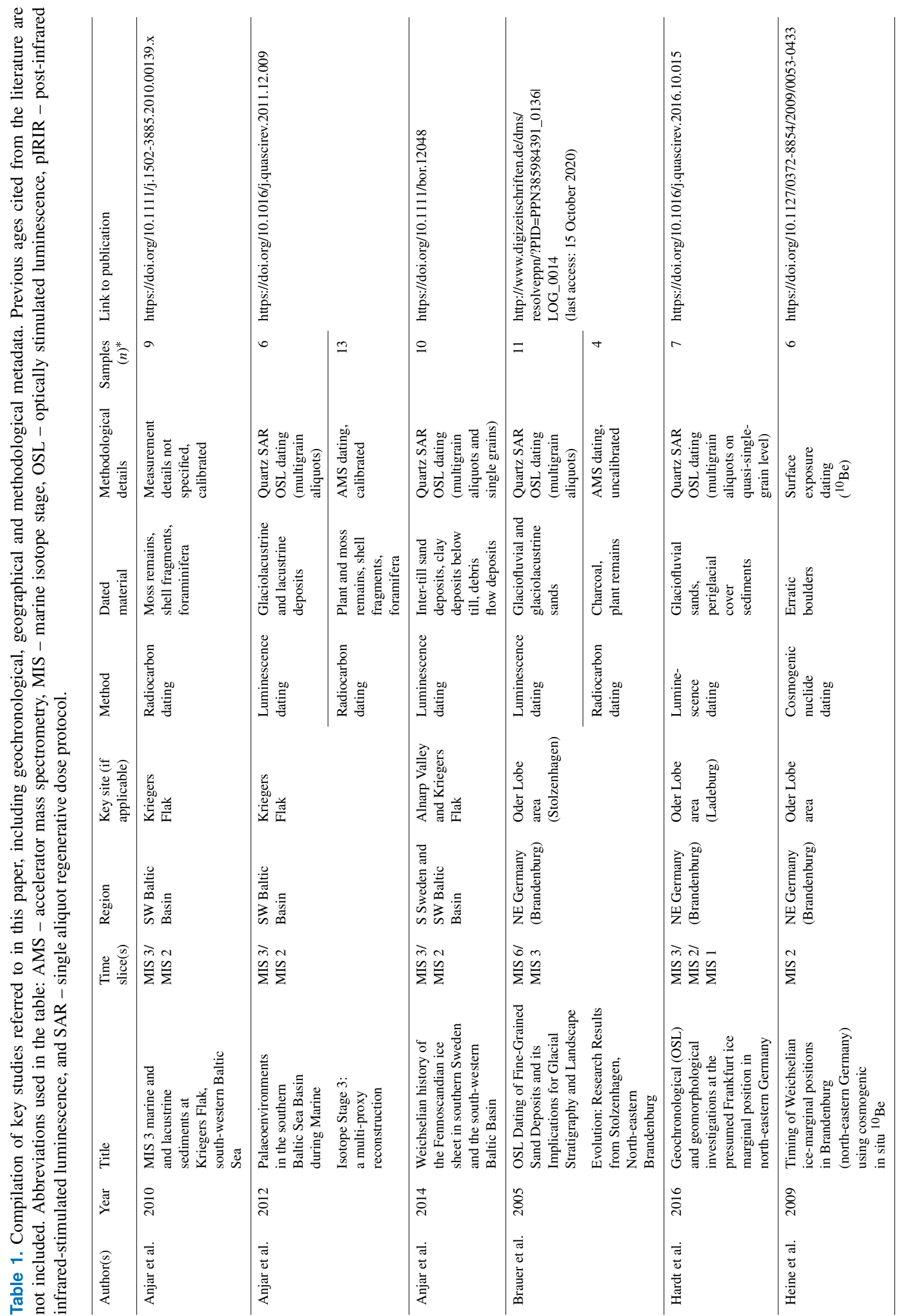




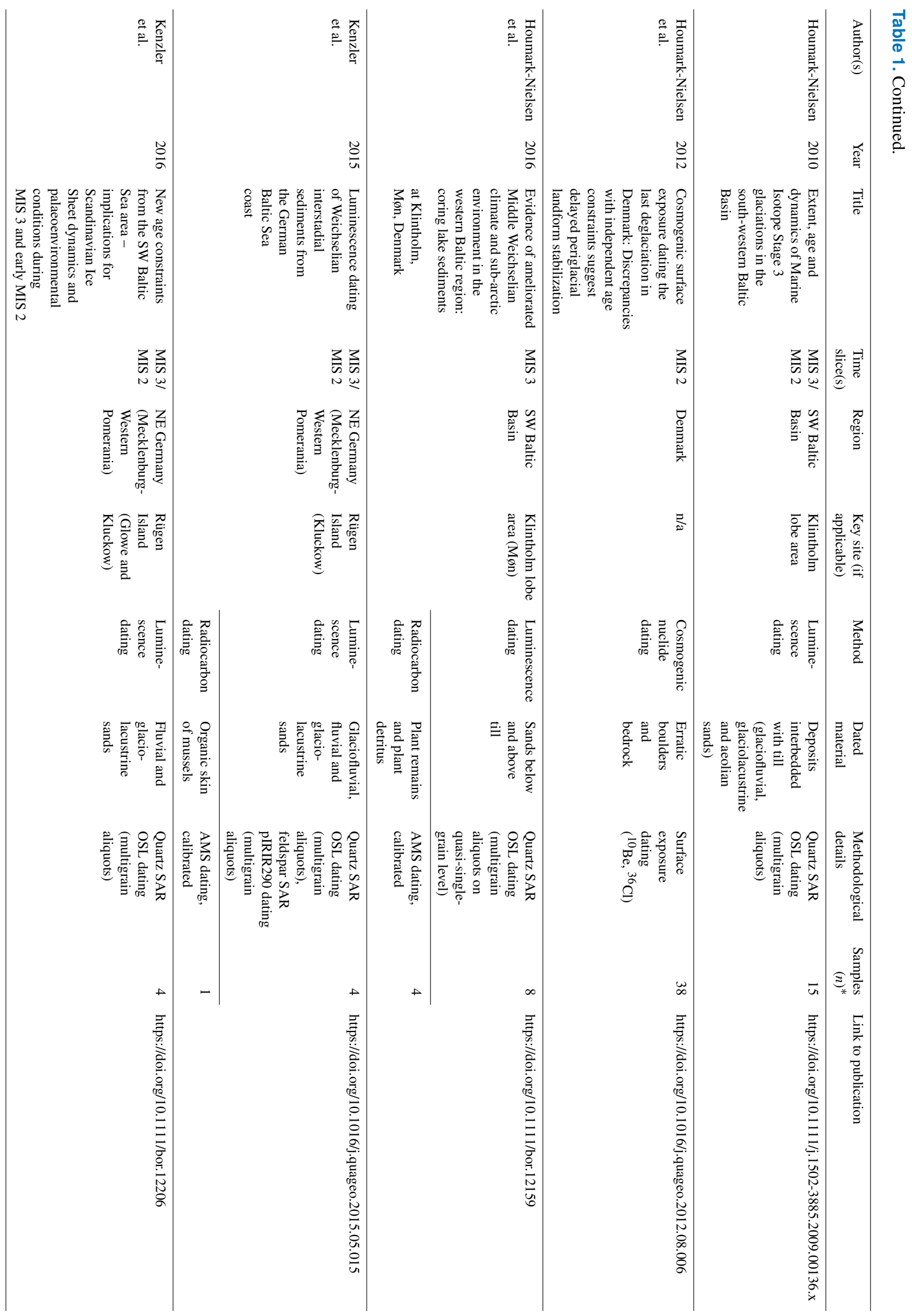




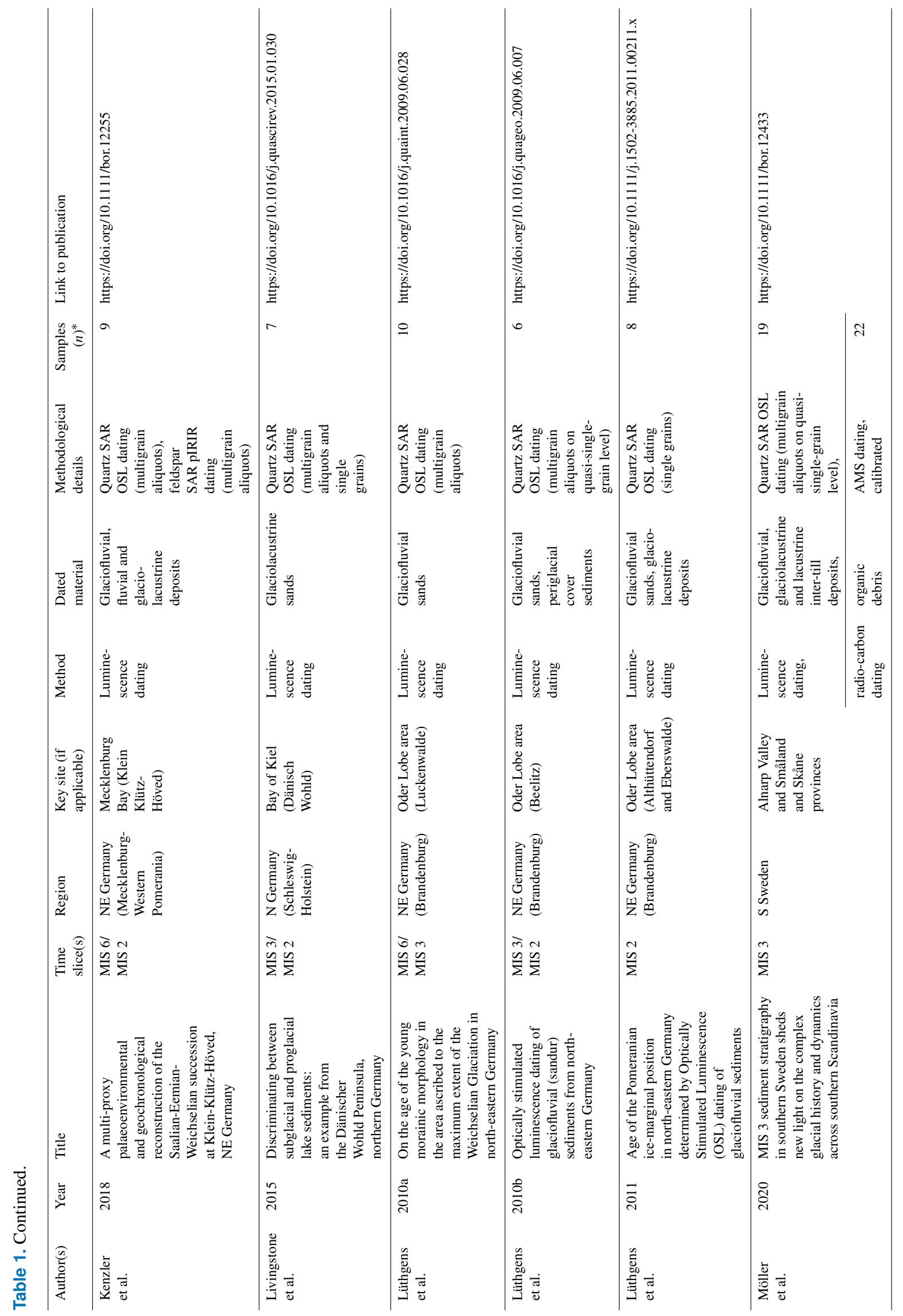




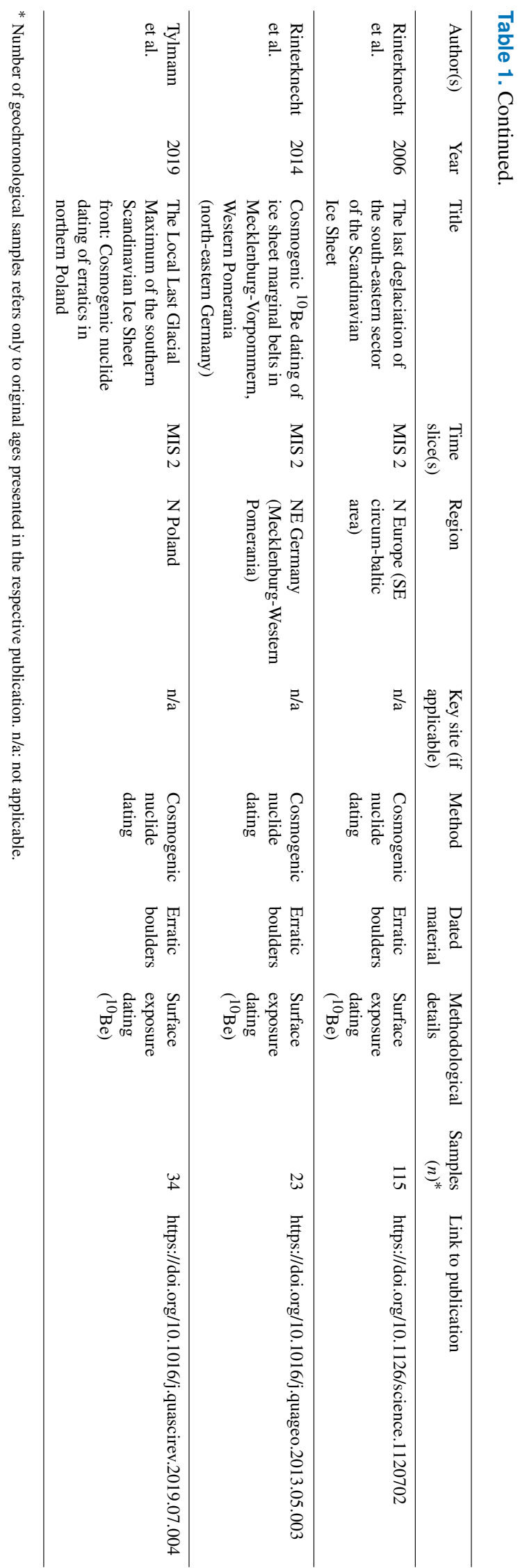

deposits. Anjar et al. (2012) postulate that the Kattegat Advance in northern Denmark dammed the Baltic Sea Basin in the time after the Klintholm Advance. Livingstone et al. (2015) have published studies about pro- and subglacial lake sediments in the Dänisch Wohld area in SchleswigHolstein. From the statistical evaluation of quartz OSL data measured as a single aliquot and single grain protocol, the authors deduce an ice advance at about $23 \mathrm{ka}$.

On the island of Rügen, Kenzler et al. $(2015,2016)$ and Pisarska-Jamroży et al. (2018) have studied and dated outcrops by quartz OSL with large aliquots from the Jasmund peninsula. The materials dated are glaciofluvial sands below the only Weichselian till. All profiles show a till younger than $22 \mathrm{ka}$ underlain by lacustrine deposits, including some sandy meltwater layers. This till is interpreted as the LGM till in the sense of the global LGM. Like at Kriegers Flak, an equivalent to the Klintholm Till has not been found (Kenzler et al., 2016, Fig. 12 therein). Hiatuses found at Kriegers Flak (Anjar et al., 2012), as well as in the Rügen profiles, are discussed as being synchronous with the Klintholm Advance in Denmark (Kenzler et al., 2016). They are related to cool climate conditions. Kenzler et al. (2015:47/48) state "this ice advance did not reach the Jasmund area". The maps in Hughes et al. (2016, Fig. 6 Band D therein) are therefore not verified. The cliff outcrop at Klein Klütz-Höved on the western flank of Wismar Bay also shows only one Weichselian till (Kenzler et al., 2018). Above Eemian deposits at the base of the section, an unconformity comprises the Early to Middle Weichselian. Deposition of fluvial to glaciofluvial sands starts at about $26 \mathrm{ka}$, and the sands directly underlying the Weichselian till are dated to $21-18 \mathrm{ka}$. All data are based on quartz OSL measurements on large aliquots. These ages are in good agreement with the timing of the Young Baltic ice advance documented by the stratigraphically youngest tills found at Kriegers Flak and in the Alnarp Valley and dated to about $20 \mathrm{ka}$ at Kriegers Flak (Anjar et al., 2014; Möller et al., 2020). The stratigraphical record at Adlergrund is less clear. Obst et al. (2016) discuss multiple Late Weichselian ice advances reworking an older till, which is now only represented by reworked clasts. This ice advance is attributed to the global LGM, but the lack of a geochronological control is hindering a coherent interpretation.

The mainland of north-eastern Germany was primarily shaped by a south-westerly branch of the Baltic Ice Stream (Fig. 1) known as the Oder Lobe (with respect to ice dynamics). Because there is no specific name describing the area formed by this lobe, this will subsequently be called the Oder Lobe area (referring to the geographic area in northeastern Germany, especially the Brandenburg and Berlin areas). Here, geochronological evidence is contrasted with the results from the German Baltic Sea coast. Multiple ages in the age range determined for the Klintholm Advance in Denmark and southern Sweden were reported. Lüthgens et al. (2010a, b) and Lüthgens and Böse (2011) provide ages for proglacial outwash sediments attributed to the maximum 
extent of the Weichselian Glaciation, here called the Brandenburg Stage, between younger than 34 and $30 \mathrm{ka}$, as determined by optically stimulated luminescence (OSL) dating of quartz single grains and small aliquots (quasi-single grains). Brauer et al. (2005) report that OSL ages from Stolzenhagen using single aliquots of quartz from outwash sediments associated with the advance of the SIS to its maximum extent at $\sim 33 \pm 2 \mathrm{ka}$ (Lüthgens et al., 2010a; Lüthgens and Böse, 2011; Hardt et al., 2016; Hardt, 2017) provide similar ages from correlate outwash sediments at the Ladeburg site of $\sim 34 \pm 5 \mathrm{ka}$ based on small aliquot (quasi-single-grain) quartz OSL. These ages are in good agreement with surface exposure ages (recalculated using the global ${ }^{10} \mathrm{Be}$ production rate of Heyman, 2014) for erratic boulders, indicating the initial down melting of the ice in the area north of the maximum position of the Weichselian Glaciation in northeastern Germany at about 24-21 ka based on Rinterknecht et al. (2006), Heine et al. (2009), and Hardt and Böse (2016). Hardt et al. (2016) have shown that the area traditionally interpreted as the Frankfurt ice-marginal position in northeastern Germany does not represent a stationary ice margin but rather a succession of ice-marginal fans that were formed at $\sim 26.3 \pm 3.7 \mathrm{ka}$ during the retreat of the ice from the maximum position it had reached during late MIS 3.

The ice advance, synchronous with the global LGM, is also well dated in north-eastern Germany. Lüthgens et al. (2011) present multiple single-grain OSL data from outwash sediments associated with the Pomeranian ice-marginal position (Althüttendorf and Eberswalde sites) dating to $20 \mathrm{ka}$. Within error, these ages are in agreement with surface exposure ages of erratic boulders from the top of the Pomeranian moraine crest in the area (initially published by Heine et al., 2009; ages recalculated using an updated ${ }^{10} \mathrm{Be}$ production rate by Hardt and Böse, 2016). The initial decay of the LGM ice is also well constrained by multiple surface exposure ages indicating that the downwasting started as early as $20-17 \mathrm{ka}$ and lasted in the hinterland until about $15 \mathrm{ka}$ (Rinterknecht et al., 2014; Heine et al., 2009; ages recalculated using an updated ${ }^{10} \mathrm{Be}$ production rate by Hardt and Böse, 2016). This process-based interpretation of the chronology of the LGM ice advance is also in good agreement with the previously summarized results from the Baltic Sea region in north-eastern Germany, Denmark and southern Sweden. In addition, it clearly is in contrast to the discussion in Rinterknecht et al. (2014) which strictly follows the concept that the Brandenburg Advance is related to the LGM at about $22 \mathrm{ka}$ and the Pomeranian Advance is younger at about $15 \mathrm{ka}$, which was based on the traditional morphostratigraphic model of a more static and synchronous SIS and on the premature interpretation of ${ }^{10} \mathrm{Be}$ exposure ages of erratic boulders.

Recently, Tylmann et al. (2019) published new cosmogenic nuclide data $\left({ }^{10} \mathrm{Be}\right)$ of erratics in the young morainic area of Poland. The interpretation of the results is also strictly linked to the traditional ice-marginal positions of the Leszno
(Brandenburg), Poznań (Frankfurt) and Pomeranian stages, and the data are documented and presented as belts from west to east.

The data give evidence of boulders with ages that do not represent the Weichselian Glaciation and a wide scatter of data of the mid-Weichselian, mainly of MIS 4 and 3 and a maximum in MIS 2 (Tylmann et al., 2019, Fig. 3 therein). The OSL data, as well as the radiocarbon ages cited by Tylmann et al. (Tylmann et al., 2019), are related to the Vistula lobe area in northern central Poland, which does not give age constraints to the Oder Lobe area and its immediate vicinity to the east.

Summing up the state of the art, the geochronological control of the dynamics of the Oder Lobe in north-eastern Germany is exceptionally coherent, based on reliable, stateof-the-art numerical dating techniques and encompassing a broad time window. Taking a process-based interpretation of the available numerical ages into account, especially the Brandenburg area, allows us to constrain the late MIS 3 ice advance as follows: it reached the area at $\sim 34 \mathrm{ka}$, stabilized at its maximum position shortly after that, most probably at $\sim 30 \mathrm{ka}$, and finally wasted down from $26 \mathrm{ka}$ onwards (Hardt et al., 2016). The ice advance correlated to the global LGM stabilized at $\sim 20 \mathrm{ka}$ and started downwasting shortly after that. To corroborate this chronology further, especially the late MIS 3 advance to the area, we have investigated new sections at the opencast lignite mine of Jänschwalde and in the Müncheberg area which will be presented in the subsequent sections.

\section{Ice dynamics and chronology of the Oder Lobe}

\subsection{Regional setting}

Recent studies confirm that the inland ice consisted of various ice streams reacting in a different way and with their own dynamic behaviour (Hughes et al., 2016). Concepts about a time transgressive formation of the outer margin and a diversified flow pattern of the British and Scandinavian inland ice started with the elaboration of dating methods of minerogenic deposits (Böse et al., 2012; Clark et al., 2012; Hughes et al., 2013).

The area of the maximum ice advance in Brandenburg is located within the so-called Oder Lobe area where the ice moved relatively far south. The sharp edge at its western border - the Weichselian Glaciation did not reach the Elbe River - implies different ice dynamics at the Oder Lobe and in the areas farther west (Fig. 4).

This south-west stretching Oder Lobe area is a low-lying area in the prolongation of the southern axis of the Baltic Sea Basin east of Bornholm. The morphology therefore facilitates an ice overflow out of the basin to the south. The landscape that was overridden by this maximum ice advance, called the Brandenburg Phase, is characterized by a till which is often patchy and less than $10 \mathrm{~m}$ thick (Juschus et al., 2011; 


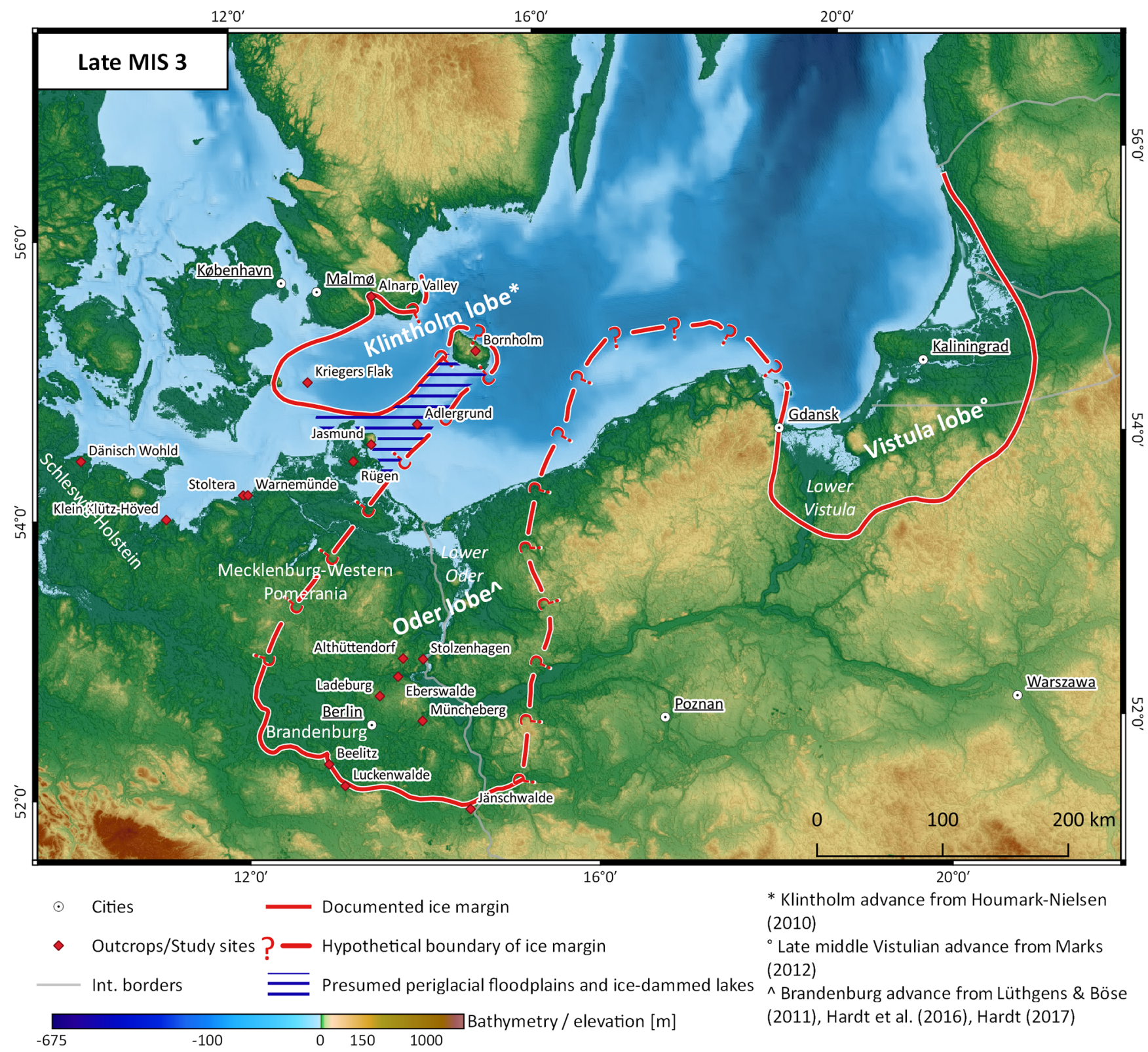

Figure 4. Configuration of the SIS during late MIS 3. Please note the lobate structure of the ice sheet, with the Oder Lobe reaching the maximum ice extent in late MIS 3 in north-eastern Germany. The island of Bornholm and the high-lying areas of the Rønne Banke separate the ice streams in the western Baltic Sea Basin. The area between Bornholm and Rügen remains ice free and is characterized by the deposition of glaciofluvial and glaciolacustrine sediments. Base map: land surface based on $250 \mathrm{~m}$ Shuttle Radar Topography Mission (SRTM) data (Jarvis et al., 2008) and bathymetry based on IOWTOPO1 and IOWTOPO2 (Seifert et al., 2001).

Lippstreu et al., 2015). Glaciofluvial sand is a widespread facies. Farther towards the outer margin, even more glaciofluvial landforms such as kames and sandurs dominate the landscape. End moraines are widely missing, and the ice margin is represented by outwash material sometimes even attached to landforms from the penultimate glacial cycle (Lüthgens et al., 2010a). Most of the elevations consist of layered sediments, interpreted as kames deposited between dead ice blocks (Weisse, 1977; Böse, 2005). In total, the ice obvi- ously was not very vigorous to transform the pre-existing landscape but mainly disguised it by meltwater sediments or subglacial meltwater features like channels (Böse, 2005). It can be hypothesized that the landscape surface was not or not deeply frozen at the end of the MIS 3 so that processes prevailed analogous to those described by MacAyeal (1993, p. 775) for the Hudson Bay area in North America where

free oscillations in the flow of the Laurentide Ice Sheet arose because the floor of Hudson Bay and 
Hudson Strait is covered with soft, unconsolidated sediment that forms a slippery lubricant when thawed. The growth phase occurs when the sediment is frozen [...]. The volume of the LIS [Laurentide Ice Sheet] slowly grows during this phase at a rate dictated by snow accumulation. The purge phase occurs when the basal sediment thaws and a basally lubricated discharge pathway (i.e. an ice stream such as those which occur in West Antarctica today) develops [...].

The stratigraphical correlation from the Baltic Sea to the maximum Weichselian ice extent in the Oder Lobe area is still a matter of discussion. The geomorphological characteristics of the area north and south of the end moraines of the Pomeranian Advance show clear differences. The Pomeranian ice-marginal position itself is characterized by a distinct and boulder-rich end moraine complex. In the hinterland, till plains widely form the landscape, whereas meltwater deposits are restricted to meltwater channels. It is notable that drumlins have been mapped in Mecklenburg-Western Pomerania only north of the Pomeranian ice-marginal position (Liedtke, 1981), whereas in the southern Oder Lobe area, formed during the Brandenburg Phase, drumlins are missing. This spatial distribution indicates differences in the dynamics of the ice and the conditions of the subglacial material frozen or unfrozen - when it was overridden and the relief was reshaped (Hermanowski et al., 2019). While the morphostratigraphical and geochronological record of the Oder Lobe area clearly shows the presence of a late MIS 3 ice advance, no evidence for such an advance was found in the above-described coastal sections. So far, the data were predominantly based on lithostratigraphical studies mainly investigating till facies at the coastal cliffs (Strahl, 2004a, b). The statistical and stratigraphical interpretations of the tills of the Stoltera cliff close to Warnemünde by Böse (1989) gave similar results as the interpretation of Müller and Strahl (Strahl, 2004b, Table 4.5.4-1 therein). The strong glaciotectonic disturbances at the Stoltera cliff nevertheless complicate the stratigraphical interpretation of the dislocated material, and the statistical evaluation only shows a distinct difference between the oldest till and the four younger ones, which show very similar characteristics (Böse, 1989, 80f., Figs. 4048).

Recently, profiles at the Baltic Sea coast, namely Klein Klütz-Höved, Kluckow, Glowe and Dwasieden, have been dated by means of OSL (Kenzler et al., 2015, 2016, 2018; Pisarska-Jamroży et al., 2018). Klein Klütz-Höved is located to the west of Wismar at the prominent coastal part between Wismar Bay and Lübeck Bay; the Kluckow and Glowe sections are at the north-western cliff of Jasmund, Rügen. All dated profiles comprise a hiatus in the Middle Weichselian. In general, the fact that unambiguous sediments of Middle Weichselian interstadials are missing in all the profiles has to be taken into consideration.
In the Kluckow section, the lowermost till is attributed to the Saalian Glaciation based on lithostratigraphic interpretation. Last interglacial deposits, as well as the Early Weichselian, are not present. However, Kenzler et al. (2015, Fig. 2 and p. 252 therein) interpret one of the stratigraphic units (Unit A in Kenzler et al., 2015) as a possible glaciofluvial sediment. This implies the presence of glacial ice in close proximity to the site older than about $62 \mathrm{ka}$. Based on the age, this could tentatively be correlated to the Ellund-Warnow ice advance. A glaciolacustrine sequence dated older than 27 to $22 \mathrm{ka}$ implies the presence of a dammed area required for the lake formation. In contrast, the underlying sandy fluvial sequence, which is older than $40 \mathrm{ka}$, shows a distinct ice wedge cast indicating a strong periglacial influence on a terrestrial surface. The first Weichselian till in this outcrop post-dates the lake deposits based on its stratigraphic position. However, when compared to the reference profile that Panzig (1995) described for north-eastern Rügen, the section exposed in the outcrop is likely incomplete because a second Weichselian till is missing. Similar interpretations are valid for the outcrop of Glowe and Dwasieden.

In the Klein Klütz-Höved profile, Krbetschek (1995; redrawn in Kenzler et al., 2018) described a Saalian till separated from the upper part of the section by Eemian deposits. According to the reference profile (Kenzler et al., 2018, Fig. 3 therein), four tills have been identified above the Eemian. However, the dated profile in the study of Kenzler et al. (2018, Fig. 4 therein) shows only one till above the interglacial deposits, and this till is attributed to the Late Weichselian (MIS 2), here associated with the Brandenburg/Frankfurt stages. OSL ages using large aliquots of quartz obtained from sandy water-lain deposits just below this till gave ages between about 29 and $17 \mathrm{ka}$. The units of sandy sediments overlying the till gave ages of about 23 to $15 \mathrm{ka}$. The hiatus between the Eemian and the dated lacustrine to (glacio-)fluvial and (glacio-)lacustrine sands is about $90 \mathrm{kyr}$ long. The onset of the fluvial to glaciofluvial sedimentation in Glowe starts roughly at the time of the Ristinge Advance in Denmark.

\subsection{The Jänschwalde and Müncheberg sites}

Given the lack of the presence of an early MIS 3 advance in the cliff sections along the Baltic Sea coast, an additional site was investigated in southern Brandenburg to further enhance the geochronological control of that ice advance. Jänschwalde is located in the area of the southernmost ice extent of the Weichselian Glaciation. Access to proglacial outwash sediments is possible because of active opencast lignite mining at Jänschwalde (Fig. 4).

The site is situated on the so-called Taubendorfer sandur. The exposed sedimentary sequence comprises complex Neogene and Quaternary deposits. During the last decades, several stratigraphical and geochronological investigations were carried out which focused on the presumed Saalian sediments 
exposed in the open cast mine (Cepek et al., 1994; Kühner, 2003; Lippstreu and Stackebrandt, 2003; Nowel, 2003; Degering and Krbetschek, 2007; Kühner, 2013; Zöller and Schmidt, 2016). The Quaternary Saalian deposits are partly overlain by silt gyttja which was classified as Eemian (MIS 5e) by palynological analyses (Kühner et al., 2008). OSL analyses of Saalian glaciofluvial sediments beneath the gyttja confirmed its Eemian origin (Zöller and Schmidt, 2016). Towards the top, the sediment succession is completed by glaciofluvial sands attributed to the sandur deposition of the maximum ice advance of the Oder Lobe. The second site, Müncheberg, is situated in the area formerly ascribed to the Frankfurt ice-marginal position (Fig. 4). In a gravel pit, sandy sediments are exposed which coarsen into coarse sand towards the top of the section (uppermost $\sim 1.5 \mathrm{~m}$ ) and are overlain by a thin layer (max. $\sim 50 \mathrm{~cm}$ ) of coarse gravel, stones and small blocks on top of the section. The covering layer is interpreted as a residual till eroded by meltwater activity, with the coarse sands deposited directly at the ice front or even subglacially. In contrast, the sandy base of the section can be interpreted as proglacial outwash sediments attributed to the ice advancing to the Brandenburg Stage of the Weichselian Glaciation. This sedimentological evidence is supported by geomorphological evidence in the surrounding area, namely the occurrence of eskers (Nitzsche, 2015). Stratigraphic logs of both sites are provided in the Supplement. We analysed nine samples from these presumed Weichselian glaciofluvial sand layers by means of quartz OSL at the Vienna Laboratory for Luminescence Dating (VLL). In addition to the basic information provided here, all methodological details concerning sample preparation, experimental setup, statistical data evaluation and age calculation are provided in the Supplement. The sample preparation was performed according to the descriptions in Hardt et al. (2016) and Lüthgens et al. (2017). We measured quartz grains in the grain size fraction of 170-250 $\mu \mathrm{m}$ (Jänschwalde) and 220 $250 \mu \mathrm{m}$ (Müncheberg). The aliquot size was $1 \mathrm{~mm}$ for the Jänschwalde samples and $2 \mathrm{~mm}$ for the Müncheberg samples, which results in an average of 15-25 grains per disc. In previous tests on Weichselian glaciofluvial material on single grains, we observed that only $3 \%-5 \%$ of the quartz grains emit a significant luminescence signal (Lüthgens et al., 2010b; Hardt et al., 2016). Thus, the measurements were done on a quasi-single-grain level, which is an important prerequisite when working on poorly bleached (glaciofluvial) material (Thrasher et al., 2009). Of the nine samples, seven were suitable for age calculation (see Hardt, 2017, and Nitzsche, 2015, for a full sample report). Owing to the observed incomplete bleaching, we applied the three-parameter Minimum Age Model (MAM; Galbraith et al., 1999) and obtained a mean age of $30 \pm 4 \mathrm{ka}(n=3)$ for the Weichselian formation of the Taubendorfer sandur in Jänschwalde and a mean age of $31 \pm 4 \mathrm{ka}(n=4)$ for the proglacial outwash sediments ascribed to the advancing ice in Müncheberg (Table S1 in the Supplement). Figures S3 to S4 in the Supplement show the ages in their sedimentary and stratigraphic contexts.

Summing up the previously published data and the new results confirming the late MIS 3 ice advance in the Oder Lobe area, this suggests a somehow scattered, incomplete and at first sight even incoherent image of the dynamics at the south-western flank of the SIS during late MIS 3 and MIS 2. Therefore, more details of the situation with respect to ice dynamics, climatic conditions and the topography of the south-western Baltic Sea area have to be discussed.

\section{Discussion}

In multiple profiles at the Baltic Sea coast in MecklenburgWestern Pomerania, up to four Weichselian tills have been identified (Stoltera, Rügen) and distinguished by lithostratigraphical studies, but the variety between the tills, as well as the subdivision into different layers within each till, is partly of poor statistical relevance (Böse, 1989). The intercalations between the tills are of fluvial, brackish, lacustrine or glaciofluvial origin. The differentiation between fluvial and glaciofluvial sediments is difficult as the reworked sands are similar in lithological and mineralogical composition. Nevertheless, the attribution to one of these sedimentary processes is crucial for the interpretation in relation to the SIS as glaciofluvial transport and deposition imply a nearby ice margin. The occurrence of ice wedge casts in those sediments implies an at least temporarily terrestrial surface during or after the deposition.

The growth and extent of the SIS is controlled by three factors.

1. The moisture supply by snow precipitation controls the growth of the SIS. The main tracks of the precipitation providing cyclones have changed during the Weichselian glacial period, and therefore the snow supply on the whole SIS was regionally changing over time. A strong regional supply has favoured the ice extent at the respective sectors. A shift of the precipitation centre from the east to the west is generally accepted for the last glacial cycle (Patton et al., 2016).

2. Ice advances are influenced by the conditions of the glacier base related to the lithology and the temperature. Warm-based glaciers on a slippery, soft, water-saturated sediment advance fast by means of basal sliding (Menzies, 1995; Hindmarsh, 2018). Meltwater even accelerates the basal slip, resulting in regionally thinning ice.

3 The topography controls the ice flow in the outer parts of the SIS (Mangerud, 2004; Roberts et al., 2018). The initial ice advance is guided by the relief. Ice flow primarily follows low-lying areas of the relief like the Baltic Sea Basin or the southerly low-lying areas of the lower Vistula and the lower Oder. Such depressions are likely to have directed the ice flow (Hermanowski, 
2015). Subsequent ice advances did not necessarily have to follow the relief because either active ice of the SIS or dead ice from previous advances remaining in depressions likely camouflaged the original relief. Consequently, a readvance was likely guided into different directions than the initial advance. Increasing ice thickness may also provoke ice transgressions to elevated areas.

Mangerud (2004, Fig. 3 therein) shows how the Baltic Sea depression as a huge catchment area influenced the ice flow during MIS 4 and 3 . The early maximum ice advance in north-west Norway is probably related to a not yet maximum extent of the sea ice in the North Atlantic, thus still providing a source of moisture for the south-western part of the SIS. The Ristinge Advance was obviously strongly influenced by the relief filling the north-western basin of the Baltic Sea. According to Fig. 9 in Kenzler et al. (2018), the Ristinge and probably Ellund-Warnow ice advances, which are not yet precisely dated, rather took place during a warming phase at the beginning of MIS 3 than during a cold phase of MIS 4 (Mangerud 2004, Fig. 2). In this case, the ice accumulated during MIS 4 and started a faster dispersion by increased flow velocities with the onset of warmer climate conditions and meltwater production. This has to be regarded in combination with the ice pressure and the geothermal influence below a growing ice mass increasing the basal temperature at the outer part of the ice sheet. This would consequently imply a thinning ice at the outer parts of the SIS. The processes controlling ice velocity in relation to temperature have recently been summarized by Patton et al. (2016). The processes driving ice dynamics at the southern flank of the SIS in early MIS 3 could be explained as a similar situation as described by Patton et al. (2016, p. 109) for the Late Weichselian maximum ice advance at the eastern fringe of the SIS, which they consider to be the result of "overstretching of the outlet glaciers" driven by ice dynamic factors.

The recent geomorphological study of Gehrmann and Harding (2018) on the glaciotectonic structures of Jasmund (Rügen) give evidence of two to three different ice pressure directions (termed "glaciotectonic complexes" by the authors) on Rügen Island. The stratigraphical interpretation follows the nomenclature used so far; therefore, they consider the whole development belonging to the MIS 2 Weichselian ice advances. However, apart from the data of Kenzler et al. (2018), no precise time constraints are available. Therefore, we propose a chronological reinterpretation of the findings of Gehrmann and Harding (2018). The oldest ice advance forming the northern glaciotectonic complex reached Rügen from a north-easterly direction. This flow direction may well be related to the early MIS 3 (Ristinge-Ellund) ice advance, which probably did not override the whole island of Rügen but just ran into its northern part (Fig. 3).

The southern glaciotectonic complex, which is interpreted to be younger than the northern one, was likely formed by the late MIS 3 ice advance which is well documented as the maximum Weichselian ice advance (Brandenburg Stage) within the Oder Lobe area. This is in accordance with the structural measurements of Lagerlund et al. (1995) who found an ice flow from a south-easterly direction on Rügen and pressure from north-west on Wolin Island. We interpret the available data as a strong indication of the presence of two outlet glaciers in late MIS 3 (Fig. 4) synchronously advancing but separated by the natural ice divide of the high-lying areas of Bornholm.

Figure 5a and c illustrate the differences in ice dynamics of the late MIS 3 advance and the early MIS 3 advance. In the stream shadow of the erosion resistant granites and gneisses, the elevated area of the Rønne Banke to the southwest of Bornholm supported the division of the ice lobes, separating the late MIS 3 ice advance through the western Baltic Sea Basin into a north-western and a southern branch. This is in excellent agreement with the geochronological evidence proving the synchronous ice advance into Denmark and southern Sweden (Klintholm Advance) and to northern Germany through the Oder depression (Brandenburg Advance). According to the dating results in the Oder Lobe area, the Oder Lobe advanced relatively quickly southward to reach the maximum Weichselian ice extent in Brandenburg, probably aided by the presence of high amounts of meltwater (Fig. 5c, d). Thus the Brandenburg ice-marginal position is, in the geochronological sense, equivalent to the occurrence of the Klintholm Till at Kriegers Flak. At the Adlergrund site, the respective till is missing probably due to erosion. The fact that the late MIS 3 ice advance did not, or at least not completely, cover the Rønne Banke and Rügen also explains the seemingly contradictory results from the cliff profiles at the Baltic Sea coast and the geochronological findings of Kenzler et al. (2018). In the Kluckow section (Kenzler et al., 2015), as well as in Klein Klütz-Höved, the late MIS 3 is represented by a hiatus in the sedimentary succession, encompassed mainly by lacustrine sediments. Given the ice configuration shown in Figs. 4 and 5d, this hiatus and/or deposition of glaciofluvial and glacio-lacustrine sediments is highly plausible. Recently, Roberts et al. (2018) presented results from the glacial environment of the today submarine Dogger Bank in the North Sea, indicating that it has been diverting ice streams from the British-Irish Ice Sheet (BIIS) during MIS 2. In addition, evidence like the occurrence of glaciolacustrine sediments indicating the existence of glacial lakes proves that also during previous ice advances, the Dogger Bank has been influencing ice flow directions. Similar to the late MIS 3 scenario in the south-western Baltic Sea area, the Dogger Bank situation proves that higher parts of the relief can direct ice flow at the outer parts of an inland ice sheet.

For the interpretation of the surface exposure data of erratics in Poland, Tylmann et al. (2019) do not take a lobate structure of the ice margin into consideration; the maximum 
(a)

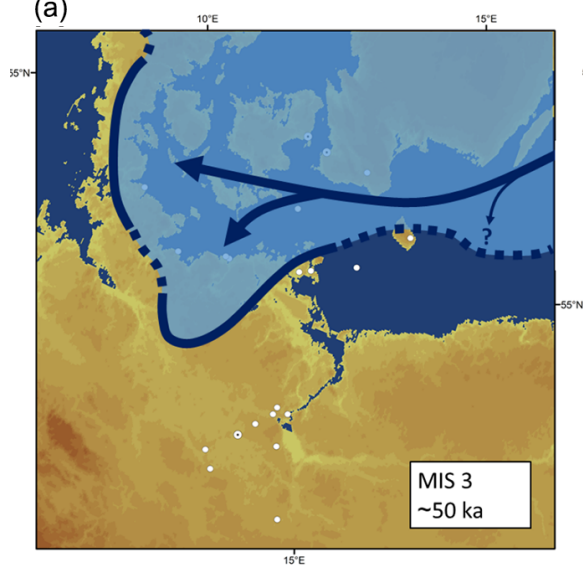

(d)

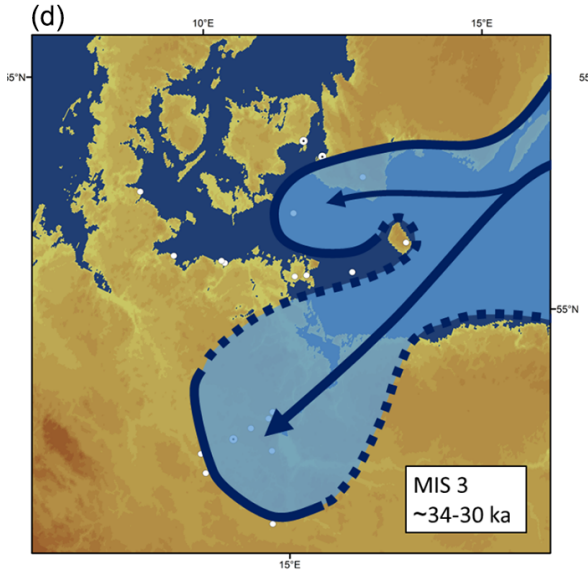

(b)

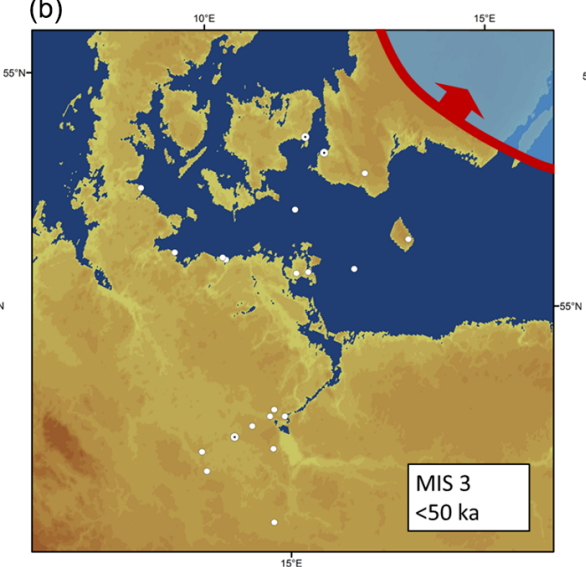

(e)

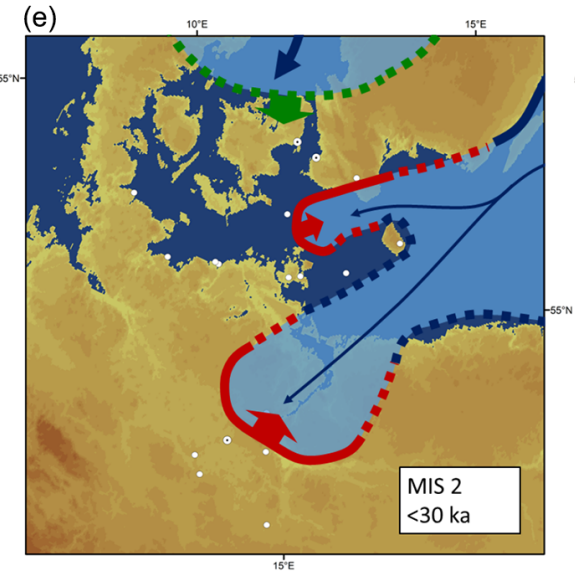

(c)

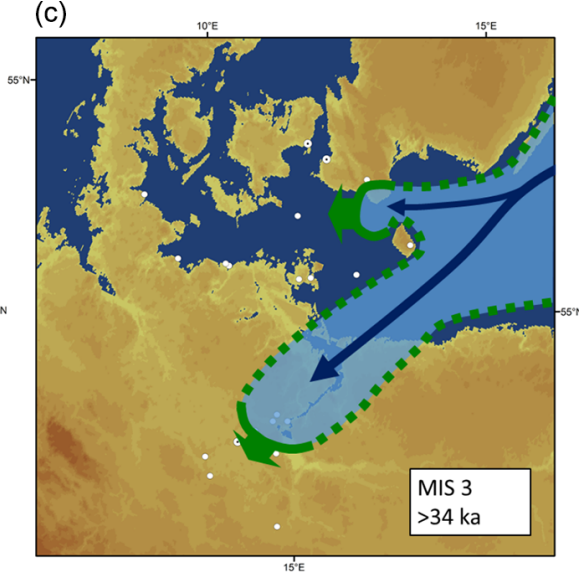

(f)

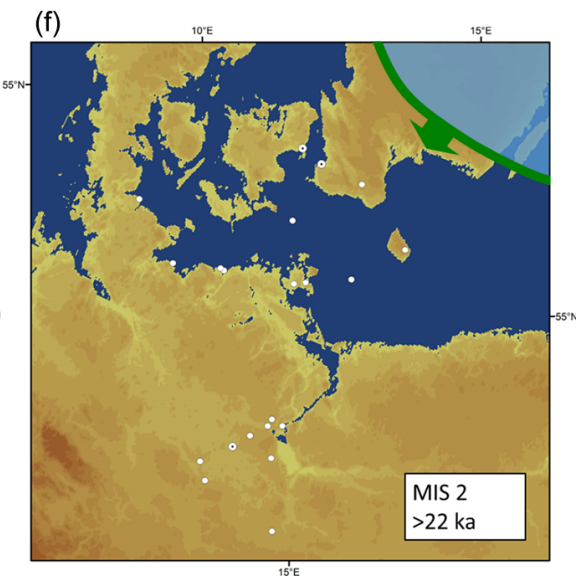

Figure 5.

ice advance in the Vistula lobe area is referred to the Poznan Phase.

In western Poland, the data offer nevertheless aspects for a different interpretation (Tylmann et al., 2019) propose a LLGM (local last glacial maximum) in western Poland between 25 and $21 \mathrm{ka}$. This is based on ages of six erratic boulders, representing the down melting of an ice advance, which gave ages within $19.3 \pm 2.1$ to $25.1 \pm 2.1 \mathrm{ka}$. The latter date has been excluded as too old from the interpretation by Tylmann et al. (2019). Nevertheless, a closer look at the map in Tylmann et al. (2019, Fig. 4) clearly shows that the data attributed to the Leszno and Poznan phases are older in the very Oder Lobe area than further to the east. They are slightly younger than the data calculated by Hardt and Böse (2016) west of the Oder river but are comparable to those originally calculated by Heine et al. (2009). Therefore, the data in western Poland support the idea of a late MIS 3 ice advance of the Oder Lobe and a different ice dynamic than in central Poland. The critical remark of Tylmann et al. (2019) that the OSL ages in Hardt et al. (2016) could be due to incomplete bleaching can be denied so far as the samples were measured on a quasi-single-grain level, which reliably allowed for the detection and correction of the data to avoid age overestima- tion. Therefore, the geochronological situation to the west of the Oder Lobe area and the relation to the ice dynamic in the Vistula lobe area have to be studied in more detail and with comparable methods.

The ice advance equivalent to the global LGM likely followed different dynamics (Fig. 5g). The till on top of the glaciotectonic complexes in Rügen as described by Gehrmann and Harding (2018) implies a frozen ground preceding the last ice advance, overriding the whole island. Kenzler et al. (2018) dated the occurrence of the first Weichselian till in the Kluckow section, as well as in Klein Klütz-Höved to $\sim 20 \mathrm{ka}$. This is time equivalent to the occurrence of the Late Baltic till beds in Denmark and southern Sweden, as documented at Kriegers Flak and in the Alnarp Valley (Anjar et al., 2014). According to the geochronological data of Lüthgens et al. (2011) and Lüthgens (2011) these tills chronologically fit with the age of the Pomeranian Advance in northern Brandenburg (Althüttendorf and Eberswalde sites) and represent the time of the climatic LGM in MIS 2. Correlation of the Pomeranian ice-marginal position with the global climatic LGM is supported by the pronounced glacial morphology with less meltwater influence of the Pomeranian icemarginal position in the Oder Lobe area (as summarized in 

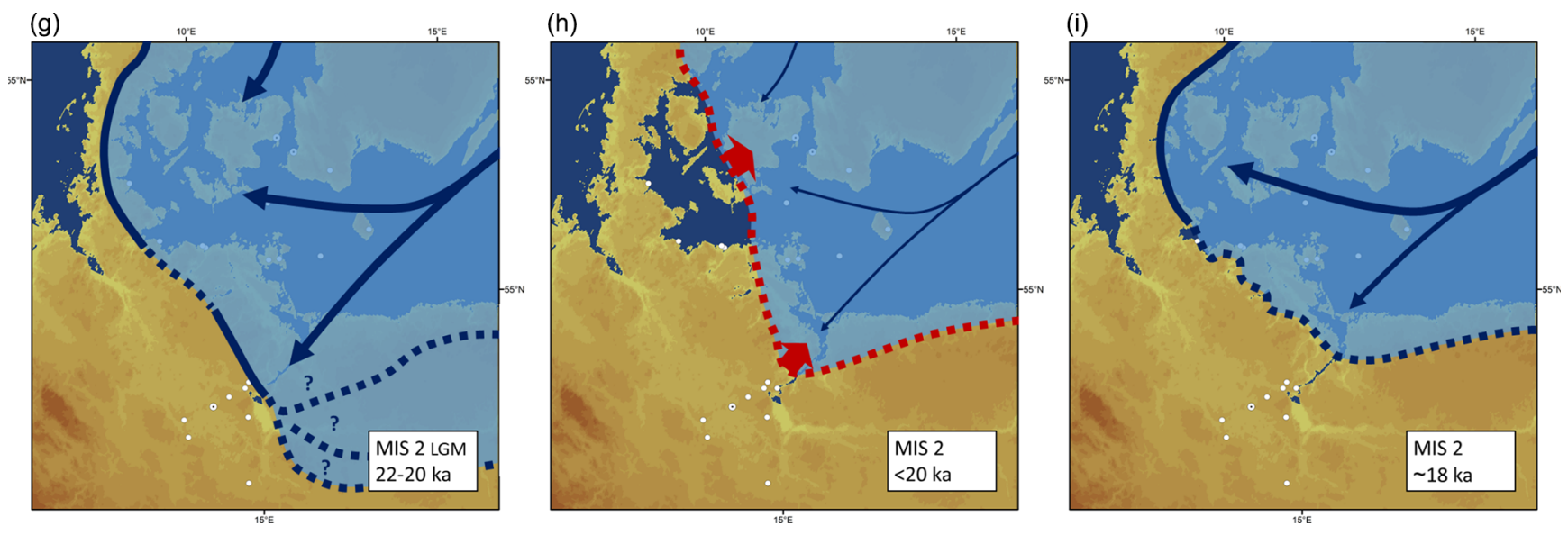

Figure 5. This figure provides a summary of the dynamics of the south-western sector of the SIS during MIS 3 and MIS 2. Please keep in mind that this figure is not meant to provide exact locations of the ice margin at any given time but is meant to illustrate the dynamics discussed in Sect. 5. For details and labels of key sites and major cities, please see Figs. 3, 4, and 6 and references cited therein. The explanation of symbols (see also Fig. 1) is as follows. Process-based interpretation of available data allows for the identification of dynamics of the ice sheet (light blue) indicated by the following: red sectors and arrows - retreat of the ice front; green sectors and arrows - advance of the ice front; and blue sectors - stability of the ice front. Whenever the location of an ice margin at a given time remains uncertain, this is indicated by dashed lines. The thickness of the blue arrows indicates the activity of the individual ice lobes inferred from the behaviour at the ice front. Detailed description: (a) the earliest ice advance of the SIS into the depicted area reached a stable ice-marginal position at $\sim 50 \mathrm{ka}$. This advance is called the Ristinge Advance in Denmark and the Ellund-Warnow Advance in northern Germany. Please also see Sect. 3.1 and Fig. 3 for details. Chronological control is still scarce and, although very likely, the contemporaneity of Ristinge, Ellund and Warnow remains to be proven. Evidence for an early MIS 3 ice advance of the SIS is only present to the north-west of an idealized line from Bornholm following the Rønne Banke to the Adlergrund site and the western part of the island of Rügen. (b) Decay of the SIS after the early MIS 3 advance after $50 \mathrm{ka}$, dated, for example, by Anjar et al. (2014) and Möller et al. (2020) in south-western Sweden. Deglaciation reached the depicted area most likely very shortly after $50 \mathrm{ka}$; however, uncertainties in the data do not currently allow for a more precise dating. (c) Early MIS 3 advance of the Baltic Ice Stream of the SIS split into two lobes by the horst of Bornholm. The advance to the west is known as the Klintholm Advance, dated in the Alnarp Valley by Anjar et al. (2014) and Möller et al. (2020) and at Kriegers Flak by Anjar et al. (2014). The advance of the south-western Oder Lobe into northern Germany is known as the Brandenburg Advance and was dated in multiple studies. Sediments associated with the advancing ice were dated by Brauer et al. (2005) and in this study (Sect. 4.1, Müncheberg site). For details, please see Fig. 4. (d) The two ice lobes reached a stable ice-marginal position at $\sim 34-30$ ka. Ice of the Klintholm Advance (extent sensu Houmark-Nielsen, 2010) deposited a till at the Kriegers Flak site (Anjar et al., 2014), and the Brandenburg Advance reached as far south as the Jänschwalde site, newly dated in this study (Sect. 4.2), corroborating the dating results from previous studies. Ice-free conditions prevailed along an idealized line from Bornholm following the Rønne Banke to the Adlergrund site and the island of Rügen (here dated by Kenzler et al., 2015, 2018). For details on the chronology of these advances and the configuration of the ice lobes, please see Sects. 3.2 (Klintholm Advance) and 4.1 (Brandenburg Advance of the Oder Lobe). (e) Ice decay from the late MIS 3 maximum into early MIS 2. The exact timing of the retreat of the ice front is only known from a few sites, including, for example, the Alnarp Valley (Möller et al., 2020) and the Ladeburg site in north-eastern Germany (dated by Hardt et al., 2016) with a contemporaneous advance of the Kattegat Ice Stream into northern Denmark (Houmark-Nielsen, 2011). (f) The initial readvance of the SIS again approaching the Baltic Sea Basin after downwasting in the early MIS 2 is documented in southern Sweden (for details, see Sect. 3.2). (g) The SIS reached a stationary ice-marginal position at about 22-20 ka. This LGM maximum extent was reached rather synchronously in the south-western sector of the SIS, and the ice advance was not split into individual lobes like during the early MIS 3 advance but was rather represented by a more uniform ice front. For details, see Sect. 3.2 and Fig. 6. The continuation towards the east in Poland remains to be discussed, with first results potentially indicating that a reinterpretation of the classical (morpho-)stratigraphy based on geochronological findings may be possible (for details, see Sect. 5). (h) Ice decay from the LGM maximum extent was initiated shortly after $20 \mathrm{ka}$, as, for example, documented in northern Germany by multiple ages of erratic boulders (recently recalculated by Hardt and Böse, 2016) which stabilized at the landscape surface after the down melting of glacial ice and cessation of intense periglacial activity. Ice-free conditions are also documented in the Jutland Peninsula (summarized in Houmark-Nielsen, 2011) and the Dänischer Wohld area (Livingstone et al., 2015). (i) The final ice advance of the SIS across the Baltic Sea Basin occurred at $\sim 18 \mathrm{ka}$. In north-eastern Germany, chronological control is still missing to reliably correlate the Young Baltic Advance in Denmark (summarized by Houmark-Nielsen, 2011) with, for example, the W3 extent (details see Fig. 6). 
Lüthgens, 2011, and Lüthgens and Böse, 2011). During the previous down melting from the late MIS 3 maximum position (Fig. 5e), the active ice margin formed a succession of recessional ice-marginal features to the north in the Berlin area and in the areas formerly attributed to the Frankfurt ice margin, where distinct ice-marginal fan structures developed (Ladeburg site; Hardt et al., 2015). This down wasting of the Oder Lobe is likely related to the final interstadial phases in MIS 3. At the same time, in northern Denmark the Kattegat Advance (Fig. 5e) started to block the fluvial system from the Baltic Sea Basin to the Norwegian channel (Houmark-Nielsen, 2011). During the coldest phase of MIS 2 the ground was freezing under severe periglacial conditions. The MIS 2 LGM ice advance happened when the temperatures rose again. Nevertheless, according to the topography and the formation of the distinct terminal moraines, the exaration features of the glacial tongue basins and the intense glacial (as opposed to glaciofluvial) sediment transport including erratic boulders give the impression of a different, more vigorous ice dynamic than in the late MIS 3 ice advance in the Oder Lobe area. The MIS 2 LGM ice advance can morphologically also be traced to the areas west of the Oder Lobe area (Fig. 5g), although geochronological data are still rare.

The LGM extent in Denmark is dated to $22-20 \mathrm{ka}$ by means of various methods including OSL (cf. HoumarkNielsen et al., 2012) and could be correlated with the Pomeranian Advance in north-eastern Germany (Fig. 5g). Ice decay after the LGM maximum was rapid, as indicated by exposure ages from erratic boulders which stabilized at the land surface after the down melting of glacial ice and cessation of intense periglacial activity (Fig. 5h).

To the east, the data of Tylmann et al. (2019) allow a correlation in the part of the Oder Lobe area sensu stricto, but further to the east the dates from the data north of the Poznan line are younger, on average less than $20 \mathrm{ka}$, and therefore the eastward connection of the $\sim 20 \mathrm{ka}$ ice advance (Pomeranian in Germany) is not clear (Figs. 5g, 6).

The final ice advance of the SIS across the Baltic Sea Basin most likely occurred at $\sim 18 \mathrm{ka}$. In north-eastern Germany, chronological control is still missing to reliably correlate the Young Baltic Advance in Denmark (summarized by Houmark-Nielsen, 2011) with, for example, the W3 extent (Fig. 5i).

\section{Conclusions}

Lithostratigraphical criteria have frequently been shown to be used with extreme care when it comes to deciphering different Weichselian ice advances. A good example is the lithostratigraphy of the Baltic Sea cliffs. In the sections of Kluckow and Klein Klütz-Höved, the hiatus at different levels are obvious by the dating results. The lithostratigraphical analyses of the Stoltera cliff, comprising more till layers, shows differentiations but only a limited statistical relevance, which means that in total all Weichselian tills are quite similar.

The increasing amount of numerical data gives new insight into the timing of various glaciogenic, glaciofluvial and glaciolacustrine processes. In Germany, and similarly in other countries, the traditional names of glacial ice advances like Brandenburg/Frankfurt, Pomeranian and the younger ones like the Mecklenburg Advance (Fig. 6) pretend to have a synchronous formation of ice-marginal positions over long distances, not taking into consideration the differences in ice dynamics at the distal part of the SIS. A process-based interpretation of available age data can provide a much deeper insight into the great differences in ice dynamics and geomorphological processes occurring in different parts of the SIS at the same time (Figs. 1, 5). The sedimentary records at areas close to a stationary ice margin and in the areas of advancing or decaying ice are different for the same time slice. Therefore, authors should carefully reconsider the application of the traditional, usually morphostratigraphically defined names of ice advances.

Regional precipitation and temperature, as well as the preexisting relief, have influenced the ice dynamics in the southwestern part of the SIS. Regional fast ice advances were the result of "outlet glaciers" (Patton et al., 2016, p. 106). Patton et al. (2016) developed a climatic model for the nourishment of the SIS by varying precipitation and the Atlantic sea circulation. Reduced precipitation in general but also a time-spatial differentiation in the climatic deterioration and precipitation influenced the ice extent. For MIS 3, they suppose a restricted and still onshore ice margin in the western Norwegian part, whereas a shift in the main ice divide to the east was also changing the flow dynamic of the whole SIS.

The geochronological control compared against the background of global climatic records implies that the fast-paced ice advances are not synchronous with the coldest climate phases but happened during the onset of climate amelioration in the sense of interstadials. The Ellund-Warnow Advance during the warming of early MIS 3, following the cold stage of MIS 4, was, according to present knowledge, the first Weichselian ice advance into the south-western Baltic Sea area (Fig. 5a).

During late MIS 3, the SIS expanded through the southwestern Baltic area in a lobate fashion (Fig. 5c-e) with a westerly lobe known as the Klintholm Advance in Denmark and a southerly lobe known as the Brandenburg Advance in north-eastern Germany. The ice attained its maximum extent within the Oder Lobe area. There is no evidence that Bornholm, the Rønne Banke or Rügen were overridden by the ice. Ice-free conditions resulted in the deposition of glaciofluvial deposits, and the occurrence of ice-dammed lakes resulted in the accumulation of glaciolacustrine sediments. This also explains the absence of an MIS 3 till in the coastal cliff sections. Large parts of northern Germany and Poland were ice free throughout MIS 3 (Fig. 4) (cf. Hughes 

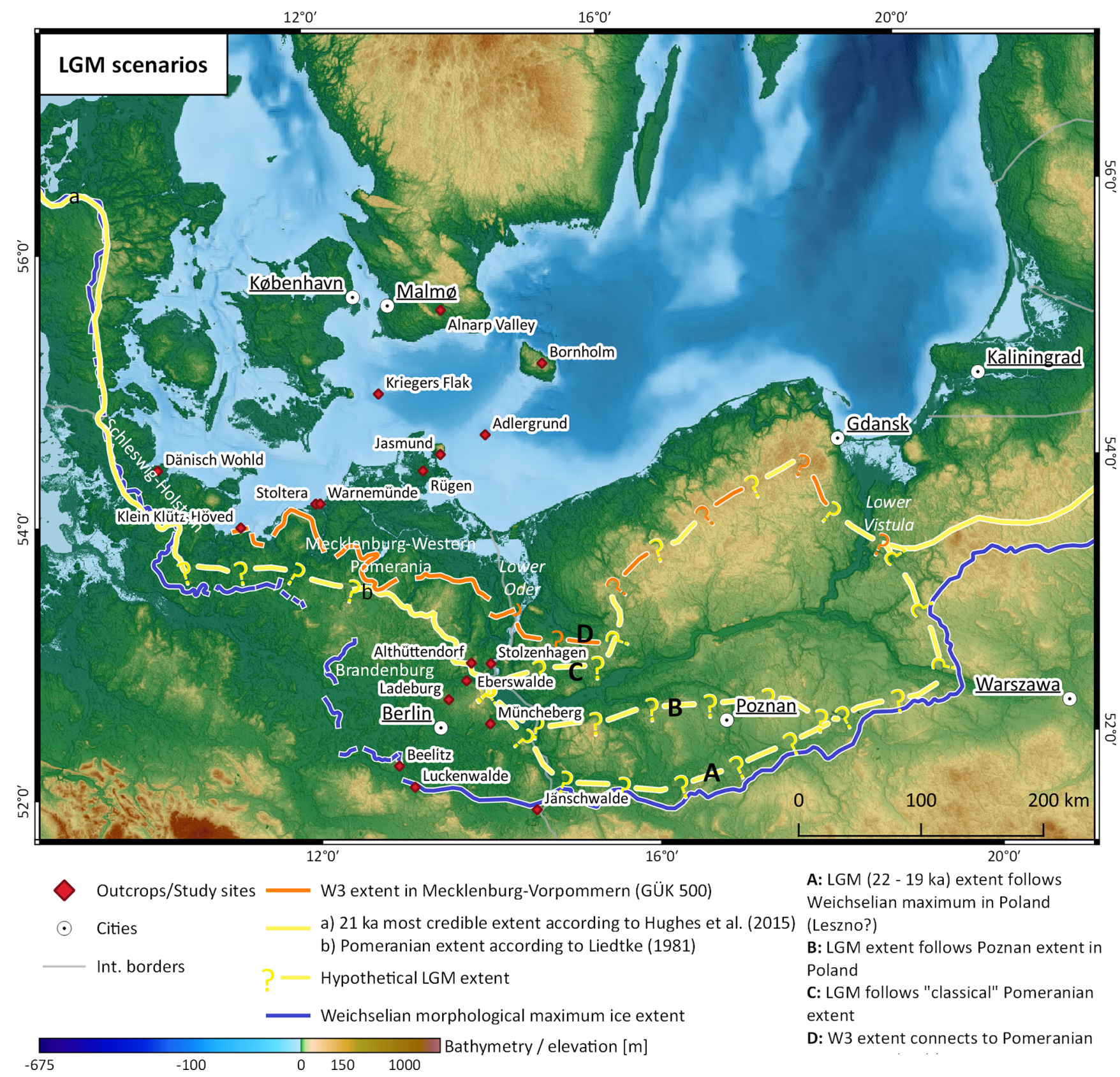

A: LGM (22 - 19 ka) extent follows Weichselian maximum in Poland

(Leszno?)

B: LGM extent follows Poznan extent in Poland

C: LGM follows "classical" Pomeranian extent

D: W3 extent connects to Pomeranian

Figure 6. Different scenarios for the configuration of the SIS during the MIS 2 global LGM. Because of the time transgressive nature of morphological ice-marginal positions, the correlation between eastern Germany and western Poland remains challenging. Geochronological control to the west of the Oder Lobe and towards northern Germany (Schleswig-Holstein) remains poor. The Mecklenburg extent is based on the geological map of Mecklenburg-Western Pomerania 1 : 500000 (Bremer and Schulz, 1994). Weichselian morphological maximum extent compiled based on Liedtke (1981) and Marks (2012). Base map: land surface based on $250 \mathrm{~m}$ Shuttle Radar Topography Mission (SRTM) data (Jarvis et al., 2008) and bathymetry based on IOWTOPO1 and IOWTOPO2 (Seifert et al., 2001).

et al., 2016). Therefore, various sedimentary environments existed in close proximity. The morphology of the late MIS 3 maximum in the Oder Lobe area is mainly formed by meltwater sediments and erosional channels, which is in accordance with the assumption of a fast-flowing ice. "Subglacial erosion processes are strongly associated with zones of fast- flowing, warm-based ice, amplified by the presence of subglacial meltwater" (Patton et al., 2016, pp. 114/115).

According to our dynamic classification, the MIS 2 LGM ice advance is represented by the Late Baltic Ice Advance in the western Baltic Sea Basin, by the Pomeranian Advance in the Oder Lobe areas and directly east of the river Oder 
within the "Odra Ice Stream" (Tylmann et al., 2019; Fig. 4) in Poland. In contrast to the previous Weichselian ice advances, the dynamics of the LGM advance were characterized not by fast-running lobate outlet glaciers but by colder and slower-moving ice probably forming a more uniform ice front (Fig. 5g) and shaping a more distinct glacial morphology. With the growing knowledge and increasing temporal and spatial availability of geochronological data of the last glacial cycle of the SIS, we strongly propose a process-based interpretation of geochronological data and a time-based definition of ice-marginal dynamics and extent as opposed to the morphostratigraphical classification expressed in the traditional terminology of the ice advances. Using the traditional terms limits the comparability of studies from different areas and neglects the increasing knowledge about the time transgressiveness of morphological ice-marginal positions. Therefore, a terminology according to the MIS stages or only indicating dating-method-based ages is strongly recommended.

Data availability. All relevant information on new OSL ages presented in this study is available from the Supplement, which includes stratigraphic logs, sample preparation and experimental setup for the OSL measurements, results from OSL measurements and gamma spectrometry, and details on statistical models and age calculation. All other relevant data are available directly in the paper (Table 1) or from the literature cited therein.

Supplement. The supplement related to this article is available online at: https://doi.org/10.5194/egqsj-69-201-2020-supplement.

Author contributions. All authors, CL, JH and MB, jointly contributed to the development of the new conceptual model presented in the study. MB and CL led the writing of the paper with contributions from JH. Visualization was jointly conceptualized by all authors and primarily implemented by JH (maps) and CL (ice dynamic models). The sampling campaigns for the newly presented OSL ages were initiated by MB and CL. OSL dating was conducted by $\mathrm{CL}$ and $\mathrm{JH}$.

Competing interests. Christopher Lüthgens currently is and Margot Böse formerly was chief editor of EGQSJ. Margot Böse is currently a member of the advisory board of EGQSJ. However, both authors were in no way involved in the editorial handling of the paper or the selection of reviewers or the review process.

Acknowledgements. We would like to thank Tony Reimann for many fruitful discussions on this topic and the joint sampling campaign in Jänschwalde. Chia-Han Tseng is also thanked for his help in the field during the Jänschwalde campaign. We want to thank Robert Hebenstreit for the valuable input during numerous discussions about SIS dynamics. Carolin Nitzsche is thanked for preparing and processing the OSL samples of the Müncheberg site, which were part of her master's thesis. The company Vattenfall is thanked for granting access to the Jänschwalde opencast mine for OSL sampling. Last but not least, the two reviewers are thanked for their valuable input, which greatly helped to improve the paper.

Financial support. We acknowledge support from the OpenAccess Publication Initiative of Freie Universität Berlin.

Review statement. This paper was edited by Sven Lukas and reviewed by Anna L. C. Hughes and Tony Reimann.

\section{References}

Anjar, J., Larsen, N., Björck, S., Adrielsson, L., and Filipsson, H.: MIS 3 marine and lacustrine sediments at Kriegers Flak, southwestern Baltic Sea, Boreas, 39, 360-366, 2010.

Anjar, J., Adrielsson, L., Bennike, O., Björck, S., Filipsson, H.L., Groeneveld, J., Knudsen, K. L., Larsen, N. K., and Möller, P.: Palaeoenvironments in the southern Baltic Sea Basin during Marine Isotope Stage 3: a multi-proxy reconstruction, Quaternary Sci. Rev., 34, 81-92, 2012.

Anjar, J., Adrielsson, L., Larsen, N.K., Möller, P., and Barth, K.: Weichselian history of the Fennoscandian ice sheet in southern Sweden and the southwestern Baltic Basin, Boreas, 43, 608-626, 2014.

Asch, K.: The 1 : 5 Million International Geological Map of Europe and Adjacent Areas - IGME 5000, BGR, Hannover, 2005.

Böse, M.: Methodisch-stratigraphische Studien und paläomorphologische Untersuchungen zum Pleistozän südlich der Ostsee, Berliner geographische Abhandlungen, 51, https://doi.org/10.23689/fidgeo-3198, 1989.

Böse, M.: The Last Glaciation and Geomorphology, in: The Physical Geography of Western Europe, edited by: Koster, E. A., Oxford University Press, Oxford, UK, 61-74, 2005.

Böse, M., Lüthgens, C., Lee, J. R., and Rose, J.: Quaternary glaciations of northern Europe, Quaternary Sci. Rev., 44, 1-25, 2012.

Brauer, A., Tempelhoff, K., and Murray, A. S.: OSL Dating of FineGrained Sand Deposits and its Implications for Glacial Stratigraphy and Landscape Evolution: Research Results from Stolzenhagen, Northeastern Brandenburg, Die Erde, 136, 15-35, 2005.

Bremer, F. and Schulz, W.: Geologische Karte von MecklenburgVorpommern 1:500.000, Geologisches Landesamt Mecklenburg Vorpommern, Schwerin, 1994.

Cepek, A. G., Hellwig, D., and Nowel, W.: Zur Gliederung des Saale-Komplexes im Niederlausitzer Braunkohlenrevier, Brandenburgische Geowissenschaftliche Beiträge, 1, 43-83, 1994.

Clark, C. D., Hughes, A. L. C., Greenwood, S. L., Jordan, C., and Sejrup, H. P.: Pattern and timing of retreat of the last British-Irish Ice Sheet, Quaternary Sci. Rev., 44, 112-146, 2012.

Degering, D. and Krbetschek, M. R.: 11. Dating of interglacial sediments by luminescence methods, in: Developments in Quaternary Sciences, edited by: Sirocko, F., Claussen, M., Fernanda, M., Goñi, S., and Litt, T., Elsevier, Amsterdam, Boston, Heidelberg, London, New York, Oxford, Paris, San Diego, San Francisco, Singapore, Sydney, Tokyo, 157-171, 2007. 
Ehlers, J., Gibbard, P. L., Hughes, P. D. (Eds.): Chapter 1 - Introduction, in: Developments in Quaternary Sciences, Elsevier, Amsterdam, Boston, Heidelberg, London, New York, Oxford, Paris, San Diego, San Francisco, Singapore, Sydney, Tokyo, 1-14, 2011.

Galbraith, R. F., Roberts, R. G., Laslett, G. M., Yoshida, H., and Olley, J. M.: Optical dating of single and multiple grains of quartz from Jinmium rock shelter, Northern Australia: Part I, experimental design and statistical models, Archaeometry, 41, 339364, 1999.

Gehrmann, A. and Harding, C.: Geomorphological Mapping and Spatial Analyses of an Upper Weichselian Glacitectonic Complex Based on LiDAR Data, Jasmund Peninsula (NE Rügen), Germany, Geosciences, 8, 208, https://doi.org/10.3390/geosciences8060208, 2018.

Gehrmann, A. and Harding, C.: Blieschow on Jasmund - geomorphology and glacigenic landforms: keys to understanding the deformation chronology of Jasmund, DEUQUA Spec. Pub. 2, 1117, 2019.

Hardt, J.: Weichselian phases and ice dynamics of the Scandinavian Ice Sheet in Northeast Germany - A reassessment based on geochronological and geomorphological investigations in Brandenburg, Department of Geosciences, Freie Universität Berlin, Berlin, 137 pp., 2017.

Hardt, J. and Böse, M.: The timing of the Weichselian Pomeranian ice marginal position south of the Baltic Sea: A critical review of morphological and geochronological results, Quatern. Int., 478, 51-58, 2016.

Hardt, J., Hebenstreit, R., Lüthgens, C., and Böse, M.: Highresolution mapping of ice-marginal landforms in the Barnim region, northeast Germany, Geomorphology, 250, 41-52, 2015.

Hardt, J., Lüthgens, C., Hebenstreit, R., and Böse, M.: Geochronological (OSL) and geomorphological investigations at the presumed Frankfurt ice marginal position in northeast Germany, Quaternary Sci. Rev., 154, 85-99, 2016.

Heine, K., Reuther, A. U., Thieke, H. U., Schulz, R., Schlaak, N., and Kubik, P. W.: Timing of Weichselian ice marginal positions in Brandenburg (northeastern Germany) using cosmogenic in situ ${ }^{10} \mathrm{Be}, \mathrm{Z}$. Geomorphol., 53, 433-454, 2009.

Hermanowski, P.: Substratum morphology and significance during the Weichselian Odra ice lobe advance in northeast Germany and northwest Poland, Geologos, 21, 241-248, 2015.

Hermanowski, P., Piotrowski, J. A., and Szuman, I.: An erosional origin for drumlins of NW Poland, Earth Surf. Proc. Land., 44, 2030-2050, https://doi.org/10.1002/esp.4630, 2019.

Heyman, J.: Paleoglaciation of the Tibetan Plateau and surrounding mountains based on exposure ages and ELA depression estimates, Quaternary Sci. Rev., 91, 30—41, 2014.

Hindmarsh, R. C. A.: Chapter 18 - Ice Sheet and Glacier Modelling, in: Past Glacial Environments, 2nd edn., edited by: Menzies, J. and van der Meer, J. J. M., Elsevier, Amsterdam, the Netherlands, 607-663, 2018.

Houmark-Nielsen, M.: Pleistocene stratigraphy and glacial history of the central part of Denmark, B. Geol. Soc. Denmark, 36, 1189, 1987.

Houmark-Nielsen, M.: Extent, age and dynamics of Marine Isotope Stage 3 glaciations in the southwestern Baltic Basin, Boreas, 39, 343-359, 2010.

Houmark-Nielsen, M.: Pleistocene Glaciations in Denmark: ACloser Look at Chronology, Ice Dynamics and Landforms, in:
Developments in Quaternary Science, edited by: Ehlers, J., Gibbard, P. L., and Hughes, P. D., Developments in Quaternary Science, Amsterdam, the Netherlands, 15, 47-58, 2011.

Houmark-Nielsen, M., Bennike, O., Lemdahl, G., and Lüthgens, C.: Evidence of ameliorated Middle Weichselian climate and subarctic environment in the western Baltic region: coring lake sediments at Klintholm, Møn, Denmark, Boreas, 45, 347-359, 2016.

Houmark-Nielsen, M., Linge, H., Fabel, D., Schnabel, C., Xu, S., Wilcken, K. M., and Binnie, S.: Cosmogenic surface exposure dating the last deglaciation in Denmark: Discrepancies with independent age constraints suggest delayed periglacial landform stabilisation, Quat. Geochronol., 13, 1-17, 2012.

Hughes, A. L. C., Gyllencreutz, R., Lohne, Ø. S., Mangerud, J., and Svendsen, J. I.: The last Eurasian ice sheets - a chronological database and time-slice reconstruction, DATED-1, Boreas, 45, 1-45, 2016.

Hughes, P. D., Gibbard, P. L., and Ehlers, J.: Timing of glaciation during the last glacial cycle: evaluating the concept of a global 'Last Glacial Maximum' (LGM), Earth-Sci. Rev., 125, 171-198, 2013.

Jakobsen, P. R.: Rock-cored drumlins on Bornholm, Denmark, Geol. Surv. Den. Greenl., 26, 17-20, 2012.

Jarvis, A., Reuter, H. I., Nelson, A., and Guevara, E.: Hole-filled seamless SRTM data V4, International Centre for Tropical Agriculture (CIAT), available at: http://srtm.csi.cgiar.org (last access: 15 October 2020), 2008.

Juschus, O., Schlaak, N., Bauriegel, A., Kowalski, S., and Bussert, R.: Geologische und bodenkundliche Untersuchungen entlang der Erdgasleitung OPAL in Brandenburg - erste Ergebnisse, Brandenburgische Geowissenschaftliche Beiträge, 18, 29-70, 2011 (in German, with English summary).

Kenzler, M., Rother, H., Hüneke, H., Frenzel, P., Strahl, J., Tsukamoto, S., Li, Y., Meng, S., Gallas, J., and Frechen, M.: A multi-proxy palaeoenvironmental and geochronological reconstruction of the Saalian-Eemian-Weichselian succession at Klein Klütz Höved, NE Germany, Boreas, 47, 114-136, 2018.

Kenzler, M., Tsukamoto, S., Meng, S., Frechen, M., and Hüneke, H.: New age constraints from the SW Baltic Sea area - implications for Scandinavian Ice Sheet dynamics and palaeoenvironmental conditions during MIS 3 and early MIS 2, Boreas, 46, 34-52, https://doi.org/10.1111/bor.12206, 2016.

Kenzler, M., Tsukamoto, S., Meng, S., Thiel, C., Frechen, M., and Hüneke, H.: Luminescence dating of Weichselian interstadial sediments from the German Baltic Sea coast, Quat. Geochronol., 30, 251-256, 2015.

Krbetschek, M.: Lumineszenz-Datierung quartärer Sedimente Mittel-, Ost- und Norddeutschlands, Fakultät für Geowissenschaften, Geotechnik und Bergbau, TU Bergakademie Freiberg, Germany, 1995.

Kühner, R.: Ausbildung und Gliederung des saalezeitlichen Sedimentkomplexes im Bereich der Hornoer Hochfläche (Arrangement and structure of the Saalian sediment sequence in the area of the upland plain of Horno), Brandenburgische Geowissenschaftliche Beiträge, 10, 111-121, 2003.

Kühner, R.: Die Faltenzone Radewiese-Briesnig im Tagebau Jänschwalde (Südbrandenburg) - eine warthezeitliche Eisrandlage? (The Radewiese-Briesnig fault zone in the Jänschwalde opencast mine (South Brandenburg) - a Warthian ice marginal position?), 
Brandenburgische Geowissenschaftliche Beiträge, 20, 109-116, 2013.

Kühner, R., Strahl, J., Süssmilch, P., Thieke, H., and Meng, S.: Lithologische und pollenanalytische Befunde aus dem saalefrühglazialen Fluviatilkomplex (Tranitzer Fluviatil) und dem Eem-Interglazial im Tagebau Jänschwalde, Südbrandenburg (Lithological and palynological results to the Early Saalian Fluvialtile Complex (Tranitzer Fluviatil) and the Eemian in the Jänschwalde opencast mine, South Brandenburg), Brandenburgische Geowissenschaftliche Beiträge, 15, 1-12, 2008.

Lagerlund, E., Persson, K. M., Krzyszkowski, D., Johansson, P., Dobracka, E., Dobracki, R., and Panzig, W.-A.: Unexpected ice flow directions during the Late Weichselian deglaciation of the south Baltic area indicated by a new lithostratigraphy in NW Poland and NE Germany, Quatern. Int., 28, 127-144, 1995.

Liedtke, H.: Die nordischen Vereisungen in Mitteleuropa, 2nd edn., 2. erw. Aufl., edited by: Zentralausschuß für Dt. Landeskunde, Trier, 1981 (in German).

Lippstreu, L. and Stackebrandt, W.: Jänschwalde und die Gliederung des Saale-Komplexes - ein Kommentar zum Beitrag von WERNER NOWEL, E\&G Quaternary Sci. J., 52, 84-90, https://doi.org/10.3285/eg.52.1.07, 2003.

Lippstreu, L., Hermsdorf, N., Sonntag, A., and Strahl, J.: Pleistozän, in: Geologie von Brandenburg, edited by: Stackebrandt, W. and Franke, D., Schweizerbart'sche Verlagsbuchhandlung, Stuttgart, Germany, 333-419, 2015.

Livingstone, S. J., Piotrowski, J. A., Bateman, M. D., Ely, J. C., and Clark, C. D.: Discriminating between subglacial and proglacial lake sediments: an example from the Dänischer Wohld Peninsula, northern Germany, Quaternary Sci. Rev., 112, 86-108, 2015.

Lüthgens, C.: The age of Weichselian main ice marginal positions in north-eastern Germany inferred from Optically Stimulated Luminescence (OSL) dating, Dissertation, Department of Earth Sciences, Freie Universität Berlin, Berlin, Germany, 2011.

Lüthgens, C. and Böse, M.: Chronology of Weichselian main ice marginal positions in north-eastern Germany, E\&G Quaternary Sci. J., 60, 17, https://doi.org/10.3285/eg.60.2-3.02, 2011.

Lüthgens, C. and Böse, M.: From morphostratigraphy to geochronology - on the dating of ice marginal positions, Quaternary Sci. Rev., 44, 26-36, 2012.

Lüthgens, C., Böse, M., and Krbetschek, M.: On the age of the young morainic morphology in the area ascribed to the maximum extent of the Weichselian glaciation in north-eastern Germany, Quatern. Int., 222, 72-79, 2010a.

Lüthgens, C., Krbetschek, M., Böse, M., and Fuchs, M. C.: Optically stimulated luminescence dating of fluvioglacial (sandur) sediments from north-eastern Germany, Quat. Geochronol., 5, 237-243, 2010b.

Lüthgens, C., Böse, M., and Preusser, F.: Age of the Pomeranian ice-marginal position in northeastern Germany determined by Optically Stimulated Luminescence (OSL) dating of glaciofluvial sediments, Boreas, 40, 598-615, 2011.

Lüthgens, C., Neuhuber, S., Grupe, S., Payer, T., Peresson, M., and Fiebig, M.: Geochronological investigations using a combination of luminescence and cosmogenic nuclide burial dating of drill cores from the Vienna Basin, Z. Dtsch. Ges. Geowiss., 168, 115$140,2017$.
MacAyeal, D. R.: Binge/purge oscillations of the Laurentide Ice Sheet as a cause of the North Atlantic's Heinrich events, Paleoceanography, 8, 775-784, 1993.

Mangerud, J.: Ice sheet limits on Norway and the Norwegian continental shelf, in: Developments in Quaternary Sciences, edited by: Ehlers, J. and Gibbard, P. L., Volume 2, Part 1, Elsevier, Amsterdam, Boston, Heidelberg, London, New York, Oxford, Paris, San Diego, San Francisco, Singapore, Sydney, Tokyo, 271-294, 2004.

Marks, L.: Timing of the Late Vistulian (Weichselian) glacial phases in Poland, Quaternary Sci. Rev., 44, 81-88, 2012.

Menzies, J. (Ed.): The dynamics of ice flow, in: Modern glacial environments: processes, dynamics and sediments, ButterworthHeinemann, Oxford, UK, 101-138, 1995.

Möller, P., Alexanderson, H., Anjar, J., and Björck, S.: MIS 3 sediment stratigraphy in southern Sweden sheds new light on the complex glacial history and dynamics across southern Scandinavia, Boreas, 49, 389-416, 2020.

Müller, U.: Weichsel-Frühglazial in Nordwest-Mecklenburg, Meyniana, 56, 81-115, 2004.

Müller, U.: Warnow-Formation, in: LithoLex online database, BGR, Hannover, available at: https://litholex.bgr.de (last access: 15 October 2020), 2006.

Nitzsche, C.: Zur Geochronologie der Sedimentablagerung im Bereich des Müncheberger Sanders, unpublished master thesis, Department of Geosciences, Physical Geography, Freie Universität Berlin, 2015.

Nowel, W.: Zur Korrelation der Glazialfolgen im Saale-Komplex Nord- und Mitteldeutschlands am Beispiel des Tagesbaus Jänschwalde in Brandenburg, E\&G Quaternary Sci. J., 52, 47-83, https://doi.org/10.3285/eg.52.1.06, 2003.

Obst, K., Nachtweide, C., and Müller, U.: Late Saalian and Weichselian glaciations in the German Baltic Sea documented by Pleistocene successions at the southeastern margin of the Arkona Basin, Boreas, 46, 18-33, https://doi.org/10.1111/bor.12212, 2016.

Panzig, W.-A.: The tills of NE Rügen - lithostratigraphy, gravel composition and relative deposition directions in the southwestern Baltic region, in: Glacial Deposits in North-East Europe, edited by: Ehlers, J., Kozarski, S., and Gibbard, P., A.A. Balkema, 521-533, 1995.

Panzig, W.-A.: Pleistocene cliff exposures on NE-Rügen (Jasmund, Wittow), Pomerania. Field symposium on glacial geology at the Baltic Sea coast in Northern Germany, The Peribaltic Group INQUA Commission on Glaciation, Excursion Guide, 40-59, 1997.

Patton, H., Hubbard, A., Andreassen, K., Winsborrow, M., and Stroeven, A. P.: The build-up, configuration, and dynamical sensitivity of the Eurasian ice-sheet complex to Late Weichselian climatic and oceanic forcing, Quaternary Sci. Rev., 153, 97-121, 2016.

Pisarska-Jamroży, M., Belzyt, S., Börner, A., Hoffmann, G., Hüneke, H., Kenzler, M., Obst, K., Rother, H., and van Loon, A. J.: Evidence from seismites for glacio-isostatically induced crustal faulting in front of an advancing land-ice mass (Rügen Island, SW Baltic Sea), Tectonophysics, 745, 338-348, 2018.

Pisarska-Jamroży, M. G., Belzyt, S., Börner, A., Hoffmann, G., Hüneke, H., Kenzler, M., Obst, K., Rother, H., Steffen, H., Steffen, R., and van Loon, T.: The sea cliff at Dwasieden: soft-sediment deformation structures triggered 
by glacial isostatic adjustment in front of the advancing Scandinavian Ice Sheet, DEUQUA Spec. Pub., 2, 61-67, https://doi.org/10.5194/deuquasp-2-61-2019, 2019.

Rinterknecht, V., Börner, A., Bourlès, D., and Braucher, R.: Cosmogenic ${ }^{10} \mathrm{Be}$ dating of ice sheet marginal belts in MecklenburgVorpommern, Western Pomerania (northeast Germany), Quat. Geochronol., 19, 42-51, 2014.

Rinterknecht, V. R., Clark, P. U., Raisbeck, G. M., Yiou, F., Bitinas, A., Brook, E. J., Marks, L., Zelcs, V., Lunkka, J. P., Pavlovskaya, I. E., Piotrowski, J. A., and Raukas, A.: The last deglaciation of the southeastern sector of the Scandinavian Ice Sheet, Science, 311, 1449-1452, 2006.

Roberts, D. H., Evans, D. J. A., Callard, S. L., Clark, C. D., Bateman, M. D., Medialdea, A., Dove, D., Cotterill, C. J., Saher, M., Cofaigh, C.Ó., Chiverrell, R. C., Moreton, S. G., Fabel, D., and Bradwell, T.: Ice marginal dynamics of the last British-Irish Ice Sheet in the southern North Sea: Ice limits, timing and the influence of the Dogger Bank, Quaternary Sci. Rev., 198, 181-207, 2018.

Schack Pedersen, S. A. and Gravesen, P.: Low- and intermediate level radioactive waste from Ris $\varnothing$, Denmark. Location studies for potential disposal areas, Report no. 3, Danmarks og Groenlands Geologiske Undersoegelser, Rapport 2010/124, Copenhagen, Denmark, 51 pp., 2010.

Seifert, T., Tauber, F., and Kayser, B.: A high resolution spherical grid topography of the Baltic Sea, 2nd edn., Proceedings of the Baltic Sea Science Congress, Stockholm, 25-29 November 2001.

Steinich, G.: Die stratigraphische Einordnung der Rügen-Warmzeit, Z. Geol. Wissenschaft., 20, 125-154, 1992.

Stephan, H.-J.: Climato-stratigraphic subdivision of the Pleistocene in Schleswig-Holstein, Germany and adjoining areas: status and problems, E\&G Quaternary Sci. J., 63, 3-18, https://doi.org/10.3285/eg.63.1.01, 2014.
Stokes, C. R. and Clark, C. D.: Palaeo-ice streams, Quaternary Sci. Rev., 20, 1437-1457, 2001.

Strahl, J.: Kliff der Stoltera westlich Warnemünde, in: Geologie von Mecklenburg-Vorpommern, editd by: Katzung, G., Schweizerbart, Stuttgart, 302-305, 2004a.

Strahl, J.: Kliffs an den Klützer Höveds, in: Geologie von Mecklenburg-Vorpommern, edited by: Katzung, G., Schweizerbart, Stuttgart, 294-297, 2004b.

Thrasher, I. M., Mauz, B., Chiverrell, R. C., and Lang, A.: Luminescence dating of glaciofluvial deposits: A review, Earth-Sci. Rev., 97, 133-146, 2009.

Tylmann, K., Rinterknecht, V. R., Woźniak, P. P., Bourlès, D., Schimmelpfennig, I., Guillou, V., and Team, A.: The Local Last Glacial Maximum of the southern Scandinavian Ice Sheet front: Cosmogenic nuclide dating of erratics in northern Poland, Quaternary Sci. Rev., 219, 36-46, 2019.

Uścinowicz, S.: The Baltic Sea continental shelf, in: Continental Shelves of the World: Their Evolution During the Last GlacioEustatic Cycle, edited by: Chiocci, F. L. and Chivas, A. R., Geological Society, Memoirs, London, 69-89, 2014.

Weisse, R.: Struktur und Morphologie von Kames und Endmoränen in den mittleren Bezirken der Deutschen Demokratischen Republik, Z. Geomorphol., Supplementary Issues, 27, 29-45, 1977.

Zöller, L. and Schmidt, C.: OSL-Altersbestimmungen an den spätsaale- bis eemzeitlichen Ablagerungen von Jänschwalde, Sonderband Brandenburgische geowissenschaftliche Beiträge/Arbeitsberichte zur Bodendenkmalpflege in Brandenburg, 22/28, 191-197, 2016. 